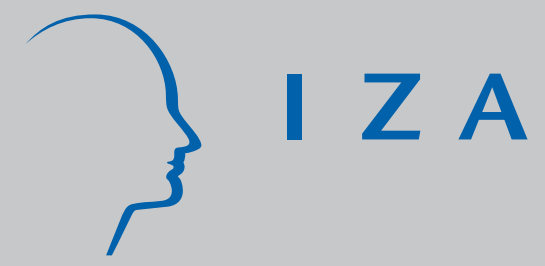

IZA DP No. 7706

U.S. versus Sweden: The Effect of Alternative In-Work Tax Credit Policies on Labour Supply of Single Mothers

Rolf Aaberge

Lennart Flood

October 2013

Forschungsinstitut zur Zukunft der Arbeit Institute for the Study of Labor 


\title{
U.S. versus Sweden: The Effect of Alternative In-Work Tax Credit Policies on Labour Supply of Single Mothers
}

\author{
Rolf Aaberge \\ Statistics Norway, \\ ESOP, University of Oslo and IZA \\ Lennart Flood \\ University of Gothenburg \\ and IZA \\ Discussion Paper No. 7706 \\ October 2013 \\ IZA
P.O. Box 7240
53072 Bonn
Germany \\ Phone: +49-228-3894-0
Fax: +49-228-3894-180
E-mail: iza@iza.org
}

Any opinions expressed here are those of the author(s) and not those of IZA. Research published in this series may include views on policy, but the institute itself takes no institutional policy positions. The IZA research network is committed to the IZA Guiding Principles of Research Integrity.

The Institute for the Study of Labor (IZA) in Bonn is a local and virtual international research center and a place of communication between science, politics and business. IZA is an independent nonprofit organization supported by Deutsche Post Foundation. The center is associated with the University of Bonn and offers a stimulating research environment through its international network, workshops and conferences, data service, project support, research visits and doctoral program. IZA engages in (i) original and internationally competitive research in all fields of labor economics, (ii) development of policy concepts, and (iii) dissemination of research results and concepts to the interested public.

IZA Discussion Papers often represent preliminary work and are circulated to encourage discussion. Citation of such a paper should account for its provisional character. A revised version may be available directly from the author. 


\title{
ABSTRACT \\ U.S. versus Sweden: The Effect of Alternative In-Work Tax Credit Policies on Labour Supply of Single Mothers
}

\begin{abstract}
An essential difference between the design of the Swedish and the US in-work tax credit systems relates to their functional forms. Where the US earned income tax credit (EITC) is phased out and favours low and medium earnings, the Swedish system is not phased out and offers 17 and 7 per cent tax credit for low and medium low incomes and a lump-sum tax deduction equal to approximately 2300 USD for medium and higher incomes. The purpose of this paper is to evaluate the efficiency and distributional effects of these two alternative tax credit designs. We pay particular attention to labour market exclusion; i.e. individuals within as well as outside the labour force are included in the analysis. To highlight the importance of the joint effects from the tax and the benefit systems it appears particular relevant to analyse the labour supply behaviour of single mothers. To this end, we estimate a structural random utility model of labour supply and welfare participation. The model accounts for heterogeneity in consumption-leisure preferences as well as for heterogeneity and constraints in job opportunities. The results of the evaluation show that the Swedish system without phase-out generates substantial larger labour supply responses than the US version of the tax credit. Due to increased labour supply and decline in welfare participation we find that the Swedish reform is self-financing for single mothers, whereas a 10 per cent deficit follows from the adapted EITC version used in this study. However, where income inequality rises modestly under the Swedish tax credit system, the US version with phase-out leads to a significant reduction in the income inequality.
\end{abstract}

JEL Classification: J22, I38

Keywords: labour supply, single mothers, in-work tax credit, social assistance, random utility model

Corresponding author:

Rolf Aaberge

Research Department

P.O. Box 8131 Dep.

Statistics Norway

0033 Oslo

Norway

E-mail: rolf.aaberge@ssb.no

\footnotetext{
* We would like to thank Tom Wennemo for skilful programming assistance and André Decoster and Torbjørn Hægeland for helpful comments. Financial support from the Norwegian Council of Research and Stiftelsen Riksbankens Jubileumsfond and Söderbergs stiftelser are gratefully acknowledged.
} 


\section{Introduction}

During the recent decades a debate in the OECD countries on reforming the tax-transfer treatment of disadvantaged households has turned on two issues. The first one concerns the possibly large loss in efficiency due to disincentives and distortions on worker behaviour caused by high effective marginal tax rates for small and medium income levels. The second issue stems from the widespread view that the system of transfers and benefits directly or indirectly related to supporting the life standard of disadvantaged households performs rather poorly in terms of cost-effectiveness. This concern motivated the Swedish Government to introduce an in-work tax credit reform "Jobbskatteavdraget” (JSA) in 2007. This reform differs from the US Earned Income Tax Credit (EITC) in two important ways. It is universal and it is not phased out and thus reduces taxes for all working individuals at all earnings levels. As a result of the reform the Swedish Government expected increased labour supply as well as a major reduction in the number of individuals depending on the welfare system ${ }^{1}$. By contrast, since the EITC is phased out at a moderate earnings level and is targeted to low-income families, redistributive concerns appear to be a major justification for its design. The purpose of this paper is to make an evaluation of whether or not phasing out the tax credit has a significant different impact on labour supply responses, poverty and income inequality for Swedish single mothers.

Moreover, since financial issues have been a major concern for introducing the tax credit reform we will also assess the effects on the governmental budget.

Single mothers stand out as the household type with the largest proportion of "outsiders" that strongly depend on support from the welfare system. ${ }^{2}$ Accordingly, it is of major importance to include "outsiders" in the population under study ${ }^{3}$. However, since it might not make sense to assume that the "outsiders" face equally attractive job opportunities as the "insiders" it is important to use a model of labour supply that account for heterogeneity in job opportunities. As will be demonstrated in Section 3 the random utility model (RUM) of household labour supply used in this study is particularly appropriate for dealing with heterogeneity in job opportunities and can be considered as an extension of the traditional random utility model. The RUM framework allows for an integrated treatment of "insiders" and "outsiders" where it is accounted for heterogeneity in preferences for consumption-leisure as well as for possible differences in job opportunities. Moreover, this analysis accounts for the impact of three means-tested arrangements; social assistance, housing allowance and cost of childcare. Thus, an important aspect of the choice environment of Swedish single mothers is the possibility to combine work with the receipt of social assistance. However, since empirical

\footnotetext{
${ }^{1}$ In Sweden the group consisting of unemployed, long-term sick and disabled has been addressed as "utanförskapet” which is most closely translated as "outsiders". For convenience this term will be used in this paper.

2 Socialstyrelsen (2012)

${ }^{3}$ Recent analyses by Maestas, Mullen and Strand (2012), French and Song (2013) and Kostøl and Mogstad (2013) give convincing justifications for why it is important to account for incentive effects for people who receive disability support.
} 
evidence suggests that eligibility for social assistance does not necessarily mean receipt of social assistance, it is required to account for the take-up behavior by treating "social assistance" as an endogenous variable and to account for heterogeneity in job opportunities which can and job opportunities which cannot be combined with the receipt of social assistance.

Most of the empirical literature on the labour supply effects of in-work tax credit analyses UK and US data for single mothers. For recent analyses of the UK tax credit design we refer to Blundell and Hoynes (2004), Blundell et al. (2000, 2008, 2009), Brewer et al. (2006, 2009), Brewer (2001, 2009), Francesconi and van der Klaauw (2007) and Blundell and Shepard (2011), and for the U.S. Meyer and Rosenbaum (2001), Blank (2002), Meyer and Holtz-Eakin (2002), Hotz and Scholz (2003), Fang and Keane (2004), Eissa and Hoynes (2004, 2011), Grogger (2003), Grogger and Karoly (2005), Moffitt (2006) and Eissa, Kleven and Kreiner (2008) ${ }^{4}$. The overall picture created by these studies is that there are strong incentive effects from tax credits, in particular at the extensive margin. Thus, the broadening of the tax credit seems to have contributed to increased labour force participation and reduced welfare participation even though the UK and US tax credits are phased out at medium low labour incomes ${ }^{5}$. Some of the studies referred to above rely on the random utility modelling approach, whereas others use a quasi-experimental approach by exploiting whether people are affected or not by tax credit reforms. The latter approach was used by Edmark, Liang, Mörk and Selin (2012) to evaluate the Swedish tax credit system. However, they conclude that "it is not possible to evaluate effects on employment of the Swedish earned income tax credit using credible quasi-experimental methods”. Only a few studies have focused attention on the joint effects from taxes and benefits on single mother's labour supply behaviour and welfare participation in Sweden. Flood et al. (2007) have analysed the effect of in-work tax credit on the labour supply and welfare participation of single mothers in Sweden, where, “outsiders” were excluded from the population under study. Lundgren et. al. (2008) evaluated the Swedish 2007/08 in-work tax credit reform on the basis of a binary logit models for unemployment, disability and long term sickness, whereas this paper offers an evaluation based on a structural random utility model.

The data used for this study is the 2004 wave from the Swedish Longitudinal Individual Data (LINDA). LINDA is based on register-information, and thus provides high-quality tax and income data. There is no problem with under-reporting of welfare participation which is a major problem in traditional survey-data. Moreover, combined with a detailed tax benefit computer program, LINDA provides exact budget-sets for any combination of wage rates and hours of work.

The paper is organized as follows. Section 2 presents the main features of the Swedish income tax and benefit systems and explains differences as well as joint features of the JSA and the EITC. The microeconomic labour supply model and the corresponding empirical specification are discussed in

\footnotetext{
${ }^{4}$ For a comparison of UK and Germany we refer to Haan and Myck (2007) and Blundell et al. (2009).

${ }^{5}$ For comprehensive reviews of the literature see Blundell (2006) and Eissa and Hoynes (2006).
} 
Section 3. Section 3 also reports estimation results and wage and income elasticities of labour supply, whilst the data are described in Appendix. The social evaluation framework used in this study is presented in Section 4. Section 5 reports the results of the tax reform evaluation and Section 6 summarizes our findings.

\section{Income taxes and benefits in Sweden}

The Swedish income tax system consists of two parts, a flat municipal tax and a progressive national tax regime for earnings as well as for taxable transfers. ${ }^{6}$ The individual is the taxation-unit and income taxes are independent of marital status. The flat municipal tax rate varies across municipalities; the average municipal tax-rate in 2012 was 31.55 per cent, the lowest 28.89 and the highest 34.32. The national tax is based on three income-brackets. Incomes lower than SEK 401,100 $\left(\$ 45,017^{7}\right)$ are tax-free, while incomes up to SEK $574,300(\$ 64,456)$ were taxed by a 20 per cent rate and incomes above SEK 574,300 were taxed by a 25 per cent rate. Apart from taxes on earnings and transfers there is also a proportional tax on income from capital of 30 per cent.

\section{Figure 2.1. Marginal tax rates and income distribution in}

2012.

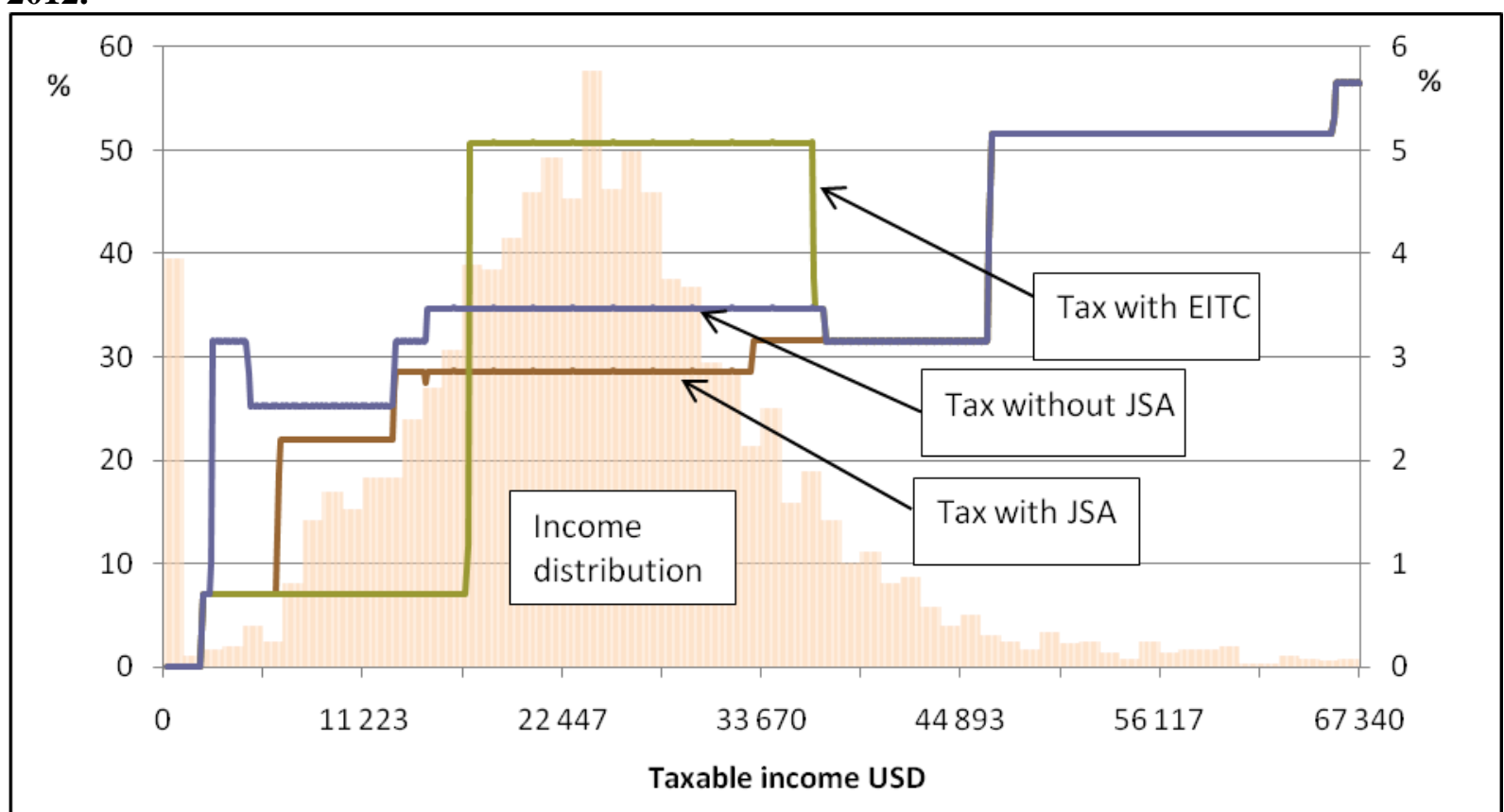

Note: Calculations based on the rules for people younger than 66 years with an income only from labor at an average municipal tax rate (31.55\%). For tax rates use left hand side axes and for income distribution use the axes on the right hand side.

\footnotetext{
${ }^{6}$ Earnings consist of wage income and income from self-employment. Taxable transfers consist of income such as sickness-, unemployment benefits, and pension income.

${ }^{7}$ Using a purchasing power adjusted exchange rate of 8.9 for 2011

( http://stats.oecd.org/Index.aspx?DataSetCode=PPPGDP).
} 
Figures 2.1 and 2.2 display the marginal and average tax rates for the income year 2012. In order to highlight the importance of the in-work tax credit reform, Figures 2.1 and 2.2 also show taxes without the credit. The marginal taxes before the reform have an irregular shape up to SEK 401,100 $(\$ 45,017)$, the break point for governmental tax. This shape is explained by the phase-in and phase-out of a basic tax deduction. This basic tax deduction remains unchanged after the reform but the tax credit is designed such that it smooth's the irregularities created by the basic deduction. The result is an increasing step-wise marginal tax rate.

The distribution of gross (taxable) income show that most single mothers face a marginal tax rate close to the municipal tax rate, only a few reach the breakpoint for governmental tax rate (13 per cent) and very few (2 per cent) pay the highest rate. Evaluation of the impact of the tax reform shows that most single mothers face lower marginal tax rates. The only exception is those that have higher incomes than approximately \$37 000. Accordingly, the average tax rate declines for everyone with a positive labour income, but much more for low than for high incomes, see Figure 2.2.

Figur 2.2. Average tax rates and income distribution in 2012.

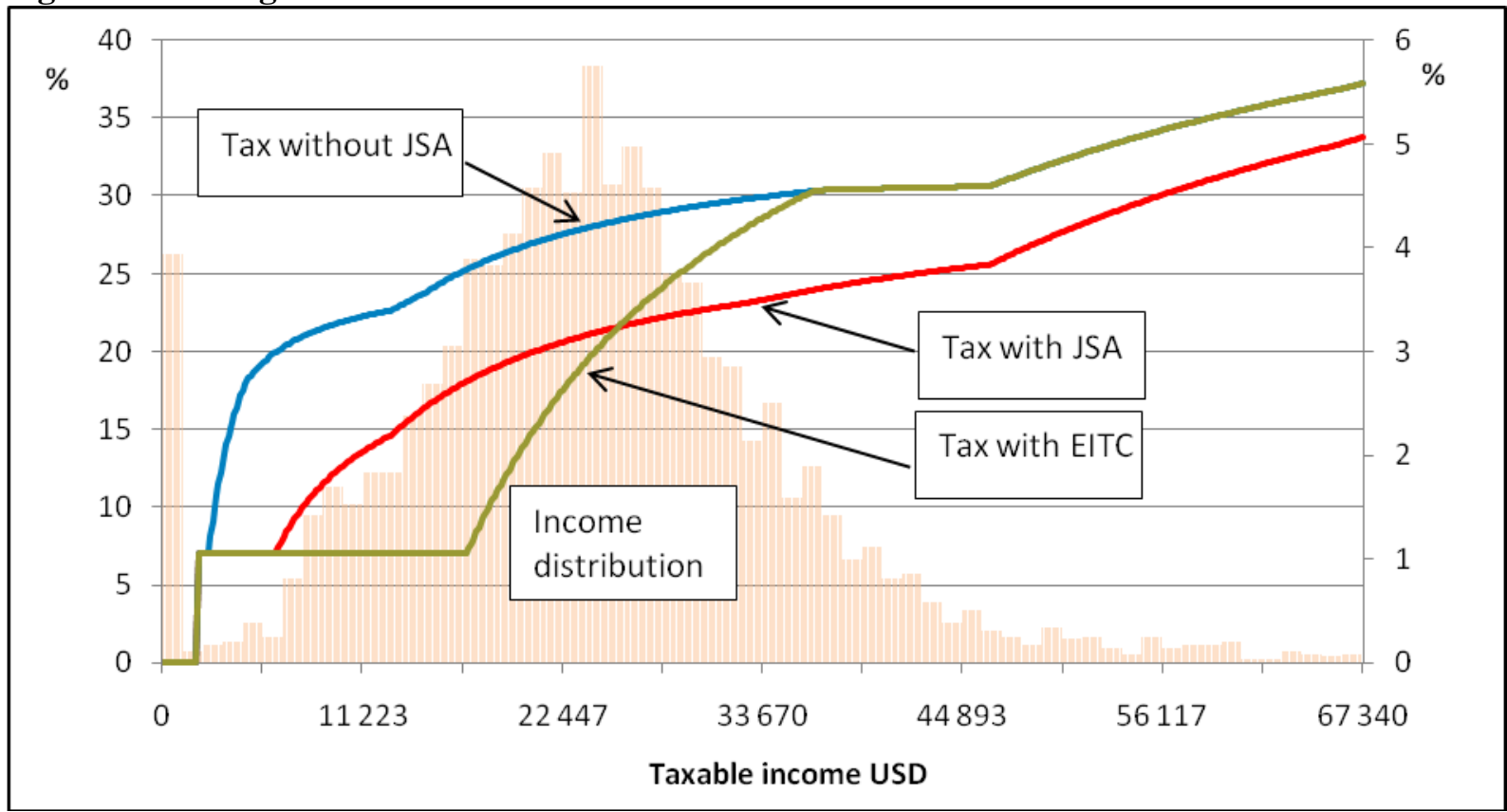

Note: Calculations based on the rules for younger than 66 with an income only from labor at an average municipal tax rate (31.55\%). For tax rates use left hand side axes and for income distribution use the axes on the right hand side.

Since the tax credit only applies for income from work, the tax reform increases the incentives for transitions to job participation for those who did not work before the reform. The incentive effects for those who were working before the reform are however mixed. Below an income of $\$ 37000$, the marginal tax rates have been reduced. For high income earners located above \$37 000, marginal tax rates are unchanged but the average taxes have declined. Accordingly, the income effect might result 
in reduced working hours for high income earners.

Although the purpose of this paper is to evaluate the 2012 JSA and a modified EITC for Swedish single mothers the result of the evaluation might be biased if we don't account for the impact of three means-tested programs; social assistance, housing allowance, and cost of childcare.

Social assistance is supposed to be the ultimate safety net for people having temporary economic problems. Individuals are not entitled to social assistance if they have money in a bank account or other assets, which mean for example that unemployment benefits, national child allowance, sickness benefits, and various pensions, must be exhausted first. Social assistance is determined by nationwide rules supposed to provide “decent” living, and thus depends on household composition. To be entitled to social assistance, a household must have an income below the maximum benefit-level. There is then an implicit tax-rate of 100 per cent on social assistance as household income increases.

Housing allowance is also determined by nationwide rules. The amount of housing allowance a household is entitled depends on household total income, rent, the number of children and the age of the parents.

The maximum-childcare fee-reform, which was implemented in 2002, is based on household income, but only up to a rather low ceiling above which the fee is constant. For the first child the fee is 3 per cent, for the second child 2 per cent, and for the third child 1 per cent of gross household income. No fees are charged for additional children. The ceiling is set fairly low, and as a result most households paid the monthly maximum amount SEK 1,260(\$137), 840(\$91), and 420(\$46) for the first, second, and third child in child care.

\subsection{Designs of the tax credit systems in Sweden and U.S.}

As indicated in Section 1 a major motivation for introducing a tax credit reform in Sweden was concern related to the fact that parts of the Swedish welfare state system performed rather poorly in terms of cost-effectiveness. In our evaluation of the implemented reform, including a comparison with the simulated performance of a hypothetical reform based on the US tax credit system, we focus attention on labour supply and income distribution effects. However, since tax reforms might have a significant effect on public finances we also report changes in income taxes, pay-roll taxes and VAT as well as in expenditure for social assistance and housing allowance.

\subsubsection{The Swedish in-work tax credit design (JSA)}

The Swedish in-work tax credit "jobbskatteavdraget (JSA)” was implemented in 2007 and became increasingly more generous in 2008, 2009 and 2010. The Swedish design differs in many respects from the EITC since it is 
o not targeted to low income households; instead everyone with an income from work receives the credit

o not dependent on family types and number of children; the only individual difference is that people older than 64 receive a more generous tax credit

o not refundable

o the credit is calculated automatically by the tax authority and the individual does not have to apply for it

o no phased-out region

o an integrated part of the means tested income for welfare programs like social assistance and housing allowance.

It should be emphasized that the Swedish in-work-tax credit is the most ambitious tax policy implemented since the large tax reform in 1991. Similarity the EITC is the largest cash transfer program in the United States

The schedule of the Swedish and the US tax credit systems are described in Table 2.1 below. Note for instance that the schedule is a function of the basic deduction as well as the municipal tax rate. Also note that there is no phased-out since the credit above \$34 606 in labour income is constant. The fact that the basic deduction is involved creates a complication because the basic deduction is determined by income from labour as well as by income from different benefits/transfers (old age and disability pension, unemployment and sickness benefits). Thus, the JSA is therefore not strictly dependent only on labour income. The municipal tax rate creates fewer complications since it is flat within each of the 290 municipalities in Sweden. ${ }^{8}$

Table 2.1 The Swedish 2012 JSA for individuals younger than 65

\begin{tabular}{|l|l|}
\hline Labour income (LI) & Tax Credit \\
P=Price amount year 2012 & BA=Basic deduction \\
$\mathrm{P}=\mathrm{SEK} 44000$ or $\$ 4$ 938* & MT=Municipal tax rate \\
\hline $0-0.91 \mathrm{P}$ & $(\mathrm{LI}-\mathrm{BA}) \mathrm{MT}$ \\
\hline $0.91 \mathrm{P}-2.72 \mathrm{P}$ & $(0.91 \mathrm{P}+0.304(\mathrm{LI}-0.91 \mathrm{P})-\mathrm{BA}) \mathrm{MT}$ \\
\hline $2.72 \mathrm{P}-7.00 \mathrm{P}$ & $(1.461 \mathrm{P}+0.095(\mathrm{LI}-2.72 \mathrm{P})-\mathrm{BA}) \mathrm{MT}$ \\
\hline $7.00 \mathrm{P}-$ & $(1.868 \mathrm{P}-\mathrm{BA}) \mathrm{MT}$ \\
\hline
\end{tabular}

Note: * Using a PPP rate of 8.9 (OECD 2011).

In order to understand the profile of the in-work-tax credit as well as the basic deduction a graphical description might be helpful. Figure 2.3 shows the profiles of the in-work tax credit system

\footnotetext{
${ }^{8}$ The average tax rate over all municipalities is 31,55\% ranging from the lowest $28.89 \%$ (Vellinge) to the highest $34.32 \%$ (Hofors).
} 
and the basic tax deduction scheme for individuals 64 years old or younger. As mentioned earlier individual older than 64 years receive more generous levels of the JSA and also a more generous level of the basic deduction. The basic deduction, which all individuals can claim, reduces taxable income (the income base for municipal and governmental tax).

Figure 2.3. EITC, JSA and basic deduction in 2012.

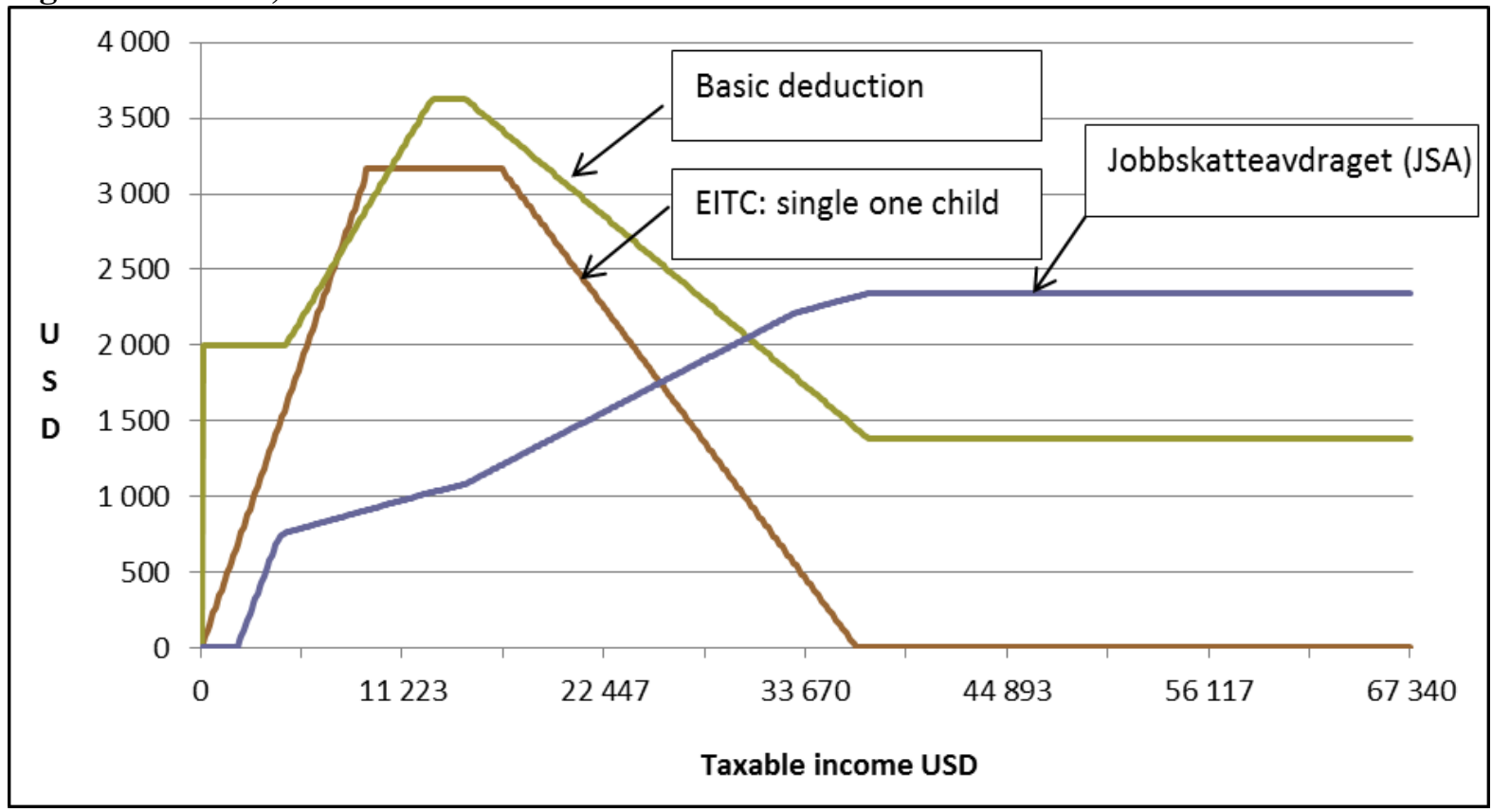

Note: Calculations based on the rules for younger than 65 with an income only from labour at an average municipal tax rate (31.55\%).

The JSA is then deducted from the municipal tax but the lowest tax is zero, which means there is no refund. The tax credit reform applies for all individuals with an income from work. The governmental budget proposal for 2012 estimates the total cost of this reform to be about $\$ 9$ billion (SEK 80 billion), provided that there are no behavioural effects from the reform..

\subsubsection{The US in-work tax credit design}

The United States Earned Income Tax Credit (EITC) is a federal tax credit for low- and medium-wage working people. The EITC was already introduced in 1975 and has since then been extended several times. On top of the federal credit twenty-five states have established their own EITCs as a supplement. In 2010 almost 27 million American families received close to \$60 billion in payments through the EITC. ${ }^{9}$ The EITC is "refundable," which means that if it exceeds a low-wage worker's income tax liability, the IRS will refund the balance. Due to its structure, the EITC is effective at targeting assistance to low-income families.

\footnotetext{
${ }^{9}$ http://www.eitc.irs.gov/central/eitcstats/
} 
For the tax year 2012, the maximum EITC for a person or couple without qualifying children is $\$ 475$, with one qualifying child it is $\$ 3,169$, with two qualifying children $\$ 5,236$, and with three or more qualifying children is $\$ 5,891$. EITC phases in slowly, the rates differ depending on family type and number of children, has a medium-length plateau, and then phases out more slowly than it phased in at 16 or 21 per cent depending on the number of children. The profiles for the different family types are presented in Figure 2.4, the actual credit is given by an IRS table which breaks down yearly income into \$50 increments. The dollar amounts are indexed annually for inflation.

\section{Figure 2.4. EITC schedule in year 2012}

\section{Value of Federal Earned Income Tax Credit, 2012}

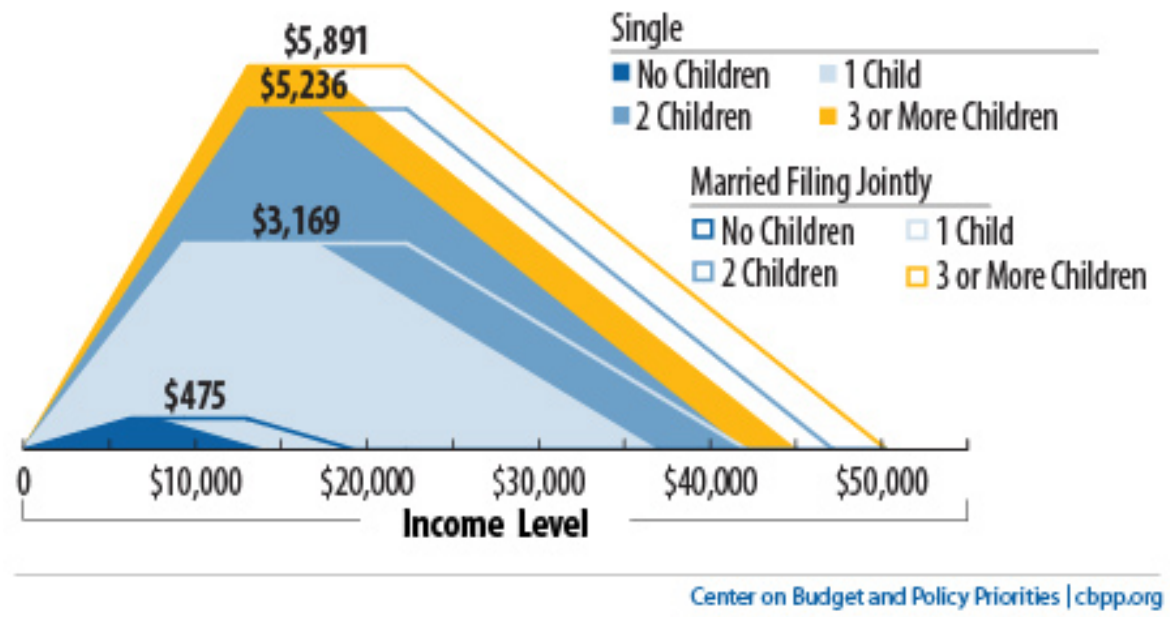

Source: http://www.cbpp.org/cms/index.cfm?fa=view\&id=2505

The main sources of earned income are wages and other taxable employee pay, net earnings from self-employment and gross income received as a statutory employee. To claim a person as one's qualifying child, the child must meet a number of requirements of relationship, age, and shared residence. Apart from the income requirement there is also a requirement that investment income cannot be greater than $\$ 3,100$.

In assessing the cost of the EITC it is important to consider the over- as well as the underutilization. It has been estimated that between 22 and 30 per cent of taxpayers claiming the EITC on their tax returns do not actually qualify for it. This led to an additional cost for the government (in 2010) of between $\$ 8$ and $\$ 10$ billion. ${ }^{10}$ At the same time, however, there are also many families who are eligible for but don't apply for the EITC. Results from analyses of the Government Accountability Office and Internal Revenue Service show that between 15 and 25 per cent of households (between 3.5 million and 7 million households) who are entitled to the EITC do not claim the credit.

\footnotetext{
${ }^{10}$ http://www.eitc.irs.gov/central/eitcstats/
} 


\subsubsection{Comparing the JSA and EITC}

As a reference Figure 2.3 also includes the EITC-profile for a single household with one child. Note the steep phase-in and out of the EITC and that JSA is not phased out. Figures 2.1 and 2.2 display the marginal and the average tax rates. The marginal tax rate without a tax credit has an irregular shape for low incomes. As mentioned earlier, this is explained by the phasing in and phasing out of the basic deduction. One way to understand the construction of JSA (see Table 2.1) is that it is designed to smooth out kinks created by the basic deduction. As follows from Figure 2.1 the ex post JSA reform marginal taxes consist of an increasing piece-wise step function with seven different rates (including zero).

The generous level of EITC together with large phase-in and -out rates create a tax profile that is very different from the current Swedish JSA-profile. First, there is a large interval with a very low tax rate, which is largely due to the effect of the basic deduction and the phase-in of the EITC. Thus the combined effect of the basic deduction and EITC are such that no tax except social security (7 per cent) is paid. However, once the phase-out of both the basic deduction and EITC begins the marginal tax rate makes a jump up to almost 50 per cent. Then the rate stays at that level until the end of the phase-out region. After that level the profile follows the other tax profile. At a higher income level the central government tax bracket increase the tax rate first by 20 per cent and then at an even higher level at an additional 5 per cent (for details see the appendix).

Figure 2.1 also includes the income distribution of the sample of single mothers used in the analyses of this paper. The low tax rate of the EITC up to a yearly income of about $\$ 16,000$ affects a substantial proportion of the income earners. However, this is also the case for the income bracket $\$ 16,000$ - $\$ 36,000$. Note that very few lone mothers pay the central governmental tax, which reflects the fact that most single mothers are low income earners. Figure 2.2 displays similar information in terms of average tax rates. Of course both JSA and EITC lower the tax rate compared to the tax without a tax credit, but their profiles show to be quite different. The EITC profile is targeted at low income household whereas the JSA benefit all households almost by the same proportion.

Since the purpose of this paper is to evaluate the effects of the Swedish and the US tax credit designs on labour supply, distribution of income and public finances for Swedish single mothers we found for comparability reasons that it was required to consider a modified version of the EITC:

- $\quad$ EITC is combined with the basic deduction

- $\quad$ the schedule for one child is applied for all single mothers

- $\quad$ not refundable

- $\quad$ included in the means tested income for social assistance and cost of child care 
The evaluation carried out in this paper uses the tax and benefit system of 2012 without inwork-tax credit as benchmark system. Next, we use a microeconometric labour supply model to simulate the effects of reforming the benchmark system by introducing JSA and EITC.

\section{The Behavioural modeling framework}

\subsection{The basic random utility model of labour supply}

The random utility model of labour supply differs from the traditional models of labour supply by characterizing behaviour in terms of a comparison between utility levels rather than between marginal variations of utility. The individuals maximize their utility by choosing from opportunity sets ( "jobs") defined by hours of work and other unobserved (by the analyst) attributes. The utility is assumed to be of the following form

$$
U(f(w h, I), h, k)=v(f(w h, I), h) \varepsilon(h, k)
$$

where $w$ is treated as a fixed wage rate whereas hours of work $h$ is treated as an endogenous variable, $I$ is exogenous income, $f$ is a tax-transfer function that transforms gross incomes into disposable income, $k$ is a variable that captures other job and/or individual characteristics and $\varepsilon$ is a random variable. Commuting time, required skill and independence in the performance of job tasks are possible examples of the characteristics captured by $k$. The model as specified in (3.1) belongs to the class of random utility models (RUM) ${ }^{11}$.

Let $A=[0, H]$ be the range of possible values for hours of work $h$. Next, by assuming that $\varepsilon$ is i.i.d. according to type I extreme value distribution it is well known that we get the following expression for the probability that a job with $h$ hours is chosen

$$
\varphi(h)=\frac{\exp (v(f(w h, I), h)}{\sum_{y \in A} \exp (v(f(w y, I), y)} .
$$

The crucial advantage of the random utility approach is that the characterization of the utility maximization problem (i.e. expression (3.1)) is not affected by the specification of $v$ nor of $f$. In other words, one can choose relatively general and complicated specifications for $v$ and/or accounting for complex tax-transfer rules $f$ without affecting the characterization of behaviour and without significantly affecting the computational burden involved by the estimation or simulation of the model. Based on (3.2), the corresponding likelihood function can then be computed and maximized in order

\footnotetext{
${ }^{11}$ See for example McFadden 1981.
} 
to estimate the parameters of the utility function. Note that expression (3.2) forms the basis of the majority of the random utility based labour supply studies ${ }^{12}$.

\subsection{The generalized random utility model of labour supply}

The specific version of the RUM approach characterized by (3.2) suffers from certain drawbacks. First, one might question the assumption of fixed wage rate, which means that job alternatives only vary by hours of work. Secondly, expression (3.2) relies implicitly on the assumption that any value in A is equally available in the market; i.e. there are no quantity constraints. By contrast, considering the choice set to be the set of market as well non-market opportunities where market opportunities (jobs) are characterized by hours of work as well as by the wage rate and other job attributes, Aaberge et al. (1999) demonstrate that ${ }^{13}$

$$
\varphi(h, w) \equiv \operatorname{Pr}\left[U(f(w h, I), h)=\max _{(x, y) \in B} U(f(x y, I), y)\right]=\frac{\exp (v(f(w h, I), h) p(w, h)}{\sum \sum_{(x, y) \in B} \exp (v(f(x y, I), y) p(x, y)} .
$$

where $B$ is the set of all opportunities available to the household (including non-market opportunities, i.e. a "job" with $w=0$ and $h=0)$ and $p(w, h)$ is the probability density function of jobs with wage rate equal to $w$ and hours equal to $h$.

An important aspect of the choice environment of Swedish single mothers is the possibility to combine work with the receipt of social assistance. However, since empirical evidence shows that eligibility for social assistance don’t necessarily mean receipt of social assistance, it is required to treat "social assistance" as an endogenous variable and at the same time make a distinction between job opportunities which can and job opportunities which cannot be combined with the receipt of social assistance. This fact requires extension of the choice set B defined in (3.2). We assume that a single mother chooses a "job" from a choice set $B$ that may differ across individuals. Each job alternative in B is characterized by a wage rate $w$, hours of work $h$ and other observed job characteristics s and/or unobserved (for the analyst) job characteristics $k$ such as environmental characteristics and skill content of the job. Note that eligibility of social assistance also will be treated as a job characteristic. Depending on the available data set some job characteristics can be observed whereas others are unobserved. Moreover, $B$ contains also non-market activities (i.e. alternative allocations of "leisure"), i.e. jobs with $w=0$ and $h=0$ that can or cannot be combined with receipt of social assistance benefit. The utility functions for single mothers are assumed to be of the following form

\footnotetext{
${ }^{12}$ See e.g. Dickens and Lundberg (1993), van Soest (1995), Flood, Hansen and Wahlberg (2004) and Labeaga, Oliver and Spadaro (2007). We refer to Aaberge, Colombino and Wennemo (2009) for an evaluation of this approach.

${ }^{13}$ Note that expression (3.3) is closely related to the continuous spatial model developed by Ben-Akiva and Watanatada (1981) and can be considered as a special case of the more general multinomial type of framework introduced by Dagsvik (1994). For previous applications, see Aaberge et al. (1995, 1999 and 2013).
} 


$$
U(f(w h, I, b(z)), h, z, s, k)=v(f(w h, I, b(z)), h, z, s) \varepsilon(w, h, z, s, k)
$$

where $v$ and $\varepsilon$ represent the systematic and the random component, respectively, $z=1$ if the single mother receives social assistance ( 0 otherwise), $b(1)$ is the social assistance benefit level $(b(0)=0), f$ is a function determined by the tax and benefit rules that transforms gross income into income after tax, i.e. $f(w h, I, b(z))$ is disposable income (income after tax and benefits), $I$ is exogenous income and $\mathrm{k}$ is a variable that is supposed to capture the impact of unobserved job characteristics. Thus, the utility of the single mother increases with her disposable income, decreases with sacrificed leisure in terms of increased hours of work. Moreover, the utility is allowed to depend on whether the chosen job is in the private or public sector as well as on job characteristics that have not been observed by the analyst. Finally, utility is also assumed to depend on whether eligible social assistance is accepted or not. The reason for treating $\mathrm{z}$ as an endogenous variable is due to the fact that there can be negative effects associated with receiving social assistance, which might explain why some people that are eligible for social assistance benefit don't accept it ${ }^{14}$. The random term $\varepsilon$ accounts for the effect on the utility of all the characteristics of the job match which are observed by the individual but not by the analyst and thus accounts for variation in tastes for a given job across individuals as well as across job opportunities for a given individual. Thus, the single mothers are assumed to make their labour supply choices according to (3.4).

By assuming that $\varepsilon$ is type I extreme value distributed and that the specification (3.4) is valid, it turns out that the probability density (3.3) for choosing a job with hours $h$ and wage rate $w$ in sector $s$, combined with deciding to receive $(z=1)$ or not to receive $(z=0)$ social assistance benefit when the single mother is eligible for social assistance, is given by

$$
\begin{aligned}
& \varphi(h, w, s, z) \equiv \operatorname{Pr}\left[U(f(w h, I, b(z)), h, s, z)=\max _{(x, y, i, j) \in B} U(f(x y, I, b(j)), y, i, j)\right]= \\
& \frac{v(f(w h, I, b(z)), h, s, z) p_{11} g_{1}(h, w, s)}{D}
\end{aligned}
$$

for $\{h, w\}>0$, where $g_{1}(h, w, s)$ is the conditional density of choice opportunities (the relative frequency (in the choice set) of opportunities with hours $h$ and wage rate $w$ in sector s) given that the single mother is eligible for social assistance, and the denominator $\mathrm{D}$ is defined by

\footnotetext{
${ }^{14}$ In Moffit (1983) this is referred to as a stigma effect.
} 


$$
D=v(f(0, I, 0), 0, \cdot, \cdot) p_{00}+\sum_{j=0,1} v(f(0, I, b(j)), 0, \cdot, j) p_{01}+
$$

$$
\sum_{i=0,1} \iint_{(x, y) \in B_{0}} v(f(x y, I, 0), y, i, \cdot) p_{10} g_{0}(x, y, i) d x d y+\quad \sum_{i=0,1} \sum_{j=0,1} \iint_{(x, y) \in B_{1}} v(f(x y, I, b(j)), y, i, j) p_{11} g_{1}(x, y, i) d x d y,
$$

where $B_{0}$ is the set of market opportunities where the single mother is not eligible for social assistance benefit and $B_{1}$ is the set of market opportunities where the single mother is eligible for social assistance benefit, $g_{0}(h, w, s)$ is the conditional relative frequency (in the choice set) of opportunities with hours $h$ and wage rate $w$ in sector s given that the single mother is not eligible for social assistance benefit and $p_{00}$ is the proportion of opportunities (in the choice set $\mathrm{B}$ ) that is nonmarket opportunities where the single mother is not eligible for social assistance benefit, $p_{01}$ is the proportion of opportunities that is non-market opportunities where the single mother is eligible for social assistance benefit, $p_{10}$ is the proportion of market opportunities where the single mother is not eligible for social assistance benefit and $p_{11}$ is the proportion of market opportunities where the single mother is eligible for social assistance benefit. Thus, $p_{00}+p_{01}+p_{10}+p_{11}=1$.

The probability of choosing a job with hours $h$ and wage rate $w$ in sector $s$ that cannot be combined with receipt of social assistance is given by

$$
\varphi(h, w, s, \cdot)=\frac{v(f(w h, I, 0), h, s, \cdot) p_{10} g_{0}(h, w, s)}{D}
$$

for $\{h, w\}>0$.

Next, let's consider the expression for $\varphi(h, w, s, z)$ when $\{h, w\}=0$. As for the market opportunity cases it is required to make a distinction between the case where the single mother is eligible for social assistance and the case where she is not eligible for social assistance. In the former case we have

$$
\varphi(0,0, \cdot, z)=\frac{v(f(0, I, b(z)), 0, \cdot, z) p_{01}}{D}
$$

whereas the latter case is given by

$$
\varphi(0,0, \cdot \cdot)=\frac{v(f(0, I, 0), 0, \cdot \cdot) p_{00}}{D}
$$


Opportunities with $h=0$ (and $w=0$ ) are non-market opportunities (i.e. alternative allocations of "leisure"). Note that the sector variable $s$ vanishes and is replaced by the symbol $\cdot$ in the nonmarket opportunity cases, whilst $z$ vanishes in the non-market cases where the single mother is not eligible for social assistance. Thus, the density defined by (3.5) - (3.9) will form the basis of estimating the parameters of the utility function and the choice sets.

\subsection{Empirical specification}

Since we observe the chosen job (s, h and w) and whether the single mother is social assistance recipient or not, the density (3.5) - (3.8) will form the basis of estimating the parameters of the utility function and the choice sets. To this end we use the following specification of the systematic part of the utility function (3.4)

$$
\begin{aligned}
& \ln v(f(w h, I, b(z)), h, z, s)=\alpha_{2}\left(\frac{f(w h, I, b(z))^{\alpha_{1}}-1}{\alpha_{1}}\right)+\left(\alpha_{4}+\alpha_{5} \log A+\alpha_{6}(\log A)^{2}+\alpha_{7} C h_{1}+\right. \\
& \left.\alpha_{8} C h_{2}+\alpha_{9} C h_{3}+\alpha_{10} s+\alpha_{11} t+\alpha_{12} z\right)\left(\frac{L^{\alpha_{3}}-1}{\alpha_{3}}\right)-\sum_{j=1}^{7} \tau_{j} Q_{j} z
\end{aligned}
$$

where $L$ is leisure, defined as $L=1-(h / 8736), s=1$ if the chosen job belongs to the public sector ( $=0$ otherwise), $z=1$ if the individual receives social assistance ( $>$ SEK 12,000) and 0 otherwise, $\mathrm{A}$ is age and $\mathrm{Ch}_{1}, \mathrm{Ch}_{2}$ and $\mathrm{Ch}_{3}$ are number of children below 1-5, 6-12 and 13-17 years old, $\mathrm{t}=1$ if the individual is unemployed, disabled or suffer from long-term sickness, and the Q-variables are defined in Table 3.1. Note that the latter term of (3.10) captures the possible disutility from being a social assistance recipient.

In the specification of the probability density of opportunities $g(h, w, s, z)$ we will assume that offered hours and offered wages are independently distributed. The justification for this is that offered hours, in particular normal working hours, are typically set in rather infrequent negotiations between employers and employees associations, while wage negotiations are far more frequent in which the hourly wage tend to be set independent of working hours. For the sake of estimation it is convenient to divide both numerator and denominator of expressions (3.2) and (3.3) by $p_{00}$ and define $\theta=\log g_{01}=\log \left(p_{01} / p_{00}\right)$ and $g_{1 z}=p_{1 z} / p_{00}$. Thus, we specify the density of opportunities in sector $s$ requiring $h$ hours of work and paying hourly wage $w$ as follows 


$$
g_{1 z} g(h, w, s, z)=g_{1 s}(w) g_{2 s}(h) g_{3}(s, z)
$$

where $g_{1 s}(w), g_{2 s}(h)$ and $g_{3}(s, z)$ are respectively the densities of wages and hours, and relative proportions of job opportunities in sector s with and without eligibility for social assistance benefit.

Dividing by $p_{00}$ and inserting for (3.11) in (3.6) we get

$$
\begin{aligned}
& \tilde{D}=v(f(0, I, 0), 0, \cdot, \cdot)+\sum_{j=0,1} v(f(0, I, b(j)), 0, \cdot, j) g_{01}+\sum_{i=0,1} \iint_{(x, y) \in B_{0}} v(f(x y, I, 0), y, i, \cdot) g_{1 i}(x) g_{2 i}(y) g_{3}(i, 0) d x d y+ \\
& \sum_{i=0,1} \sum_{j=0,1} \iint_{(x, y) \in B_{1}} v(f(x y, I, b(j)), y, i, j) g_{1 i}(x) g_{2 i}(y) g_{3}(i, 1) d x d y,
\end{aligned}
$$

We can then rewrite the choice density defined by (3.5), (3.7)-(3.9) as follows

$$
\varphi(h, w, s, z)=\frac{v(f(w h, I, b(z)), h, s, z) g_{1 s}(w) g_{2 s}(h) g_{3}(s, 1)}{\tilde{D}}
$$

for $\{h, w\}>0$, when the single mother is eligible for social assistance,

$$
\varphi(h, w, s, \cdot)=\frac{v(f(w h, I, 0), h, s, \cdot) g_{1 s}(w) g_{2 s}(h) g_{3}(s, 0)}{\tilde{D}}
$$

for $\{h, w\}>0$, when the single mother is not eligible for social assistance,

$$
\varphi(0,0, \cdot, z)=\frac{v(f(0, I, b(z)), 0, \cdot, z) g_{01}}{\tilde{D}}
$$

for $\{h, w\}=0$ when the single mother is eligible for social assistance,

and

$$
\varphi(0,0, \cdot, \cdot)=\frac{v(f(0, I, 0), 0, \cdot, \cdot)}{\tilde{D}}
$$

for $\{h, w\}=0$ when the single mother is not eligible for social assistance. 
Let us now turn to the specification of the opportunity sets given by the distributions $g_{1 s}(w), g_{2 s}(h)$ and $g_{3}(s, z)$. The sector-specific densities of offered wages are assumed to be lognormal with mean that depends on length of schooling $(E d)$ and on past potential working experience (Exp), where experience is defined to be equal to age minus length of schooling minus five, i.e.

$$
\log w=\beta_{s 0}+\beta_{s 1} \frac{\operatorname{Exp}}{100}+\beta_{s 2}\left(\frac{\operatorname{Exp}}{100}\right)^{2}+\beta_{s 3} E d_{1}+\beta_{s 4} E d_{2}+\sigma_{s} \eta
$$

where $\eta$ is standard normally distributed.

The sector-specific distributions of offered hours are composed by three segments which include a possible peak corresponding to full time ( $f t, 35.5$ - 40.5 weekly hours) and different occurrence of jobs with hours that are respectively lower and higher than full-time. Thus, $g_{2 s}$ is given by

$$
g_{2 s}(h)=\left\{\begin{array}{lll}
\exp \gamma_{s 1} & \text { if } & h \in[1,35] \\
\exp \gamma_{s 2} & \text { if } & h \in[35.5,40.5] \\
\exp \gamma_{s 3} & \text { if } & h \in[41, H],
\end{array}\right.
$$

where $H$ is the maximum observed value of $h$. Since the density values must add up to $1, \gamma_{s 3}$ for $\mathrm{s}=0,1$ is given by

$$
(35-1) \exp \gamma_{s 1}+(40.5-35.5) \exp \gamma_{s 2}+(H-41) \exp \gamma_{s 3}=1
$$

Moreover, assume that $g_{3}(s, z)$ is specified as follows

$$
\begin{aligned}
g_{3}(s, z)=\exp \left(\left(\mu_{11}+\mu_{12} t\right) s z+\left(\mu_{21}+\mu_{22} t\right) s(1-z)+\right. \\
\left.\left(\mu_{31}+\mu_{32} t\right)(1-s) z+\left(\mu_{41}+\mu_{42} t\right)(1-s)(1-z)\right)
\end{aligned}
$$

where $z=1$ if the available job opportunity can be combined with being a social assistance recipient and the $\mu$ 's are unknown parameters. In Table 3.2 we refer to $\beta, \gamma$ and $\mu$ as the parameters of the job opportunity density. 


\subsection{Estimation results and labour supply elasticities}

\subsubsection{Estimation results}

The parameters of the utility function and of the opportunity density are estimated simultaneously by the method of maximum likelihood, where the likelihood function is formed by the densities defined by (3.13) - (3.16) and the associated empirical specification (3.10) and (3.17) (3.20). The estimated parameters of the labour supply model are presented in Tables 3.1 and 3.2. Since the model are rather complex and several parameters capture non-linear or interaction effects most parameters don’t offer a simple straightforward interpretation.

The estimates displayed in Table 3.1 imply that the deterministic part of the utility function is an increasing and strictly concave function of leisure and consumption. The crucial parameters of the utility function are the shape parameters $\alpha_{1}$ and $\alpha_{3}$. These parameters are measured with high precision. Moreover, the marginal utility of leisure also depends on personal characteristics such as age and number of children for different ages, on whether the considered job is in the private or public sector and on an indicator for "outsider". As expected young children have a positive effect on the value of leisure, whereas there is no significant effect from the presence of older children. The negative value of the parameter $\alpha_{10}$ associated with choice of sector suggests that it might be easier to combine being a single mother and work in the public sector. The effect of being classified as an "outsider" $\left(\alpha_{11}\right)$ shows a strong positive effect on the value of leisure, which of course reflects low working hours in this group. Note however that the modeling framework used in this study also account for the fact that "outsiders" face poorer job opportunities than "insiders".

The estimated parameters $\left(\tau_{1}-\tau_{7}\right)$ of the disutility from being a social assistance recipient show that foreign born single mothers have a smaller disutility (smaller stigma) than an ethnic Swedish single mother. Moreover, single mothers with young children and low education get less disutility than single mothers with older children and higher education. Given that the mother is entitled to social assistance (an income below the norm), the model predicts that the take up ratio is higher for individuals with a small stigma effect.

Table 3.2 presents the parameters for the job opportunity densities. The estimated $\theta$ parameter shows as expected that more non-market opportunities than market opportunities allow to be combined with the receipt of social assistance benefit. By comparing the $\mu$ parameters of Table 3.2 we find that "outsiders” face fewer job opportunities than insiders, since the "insider” parameters are given by $\mu_{i 1}, i=1,2,3,4$ and the "outsider" parameters are given by $\mu_{i 1}+\mu_{i 2}, i=1,2,3,4$. However, since $\mu_{32}$ is not significantly different from 0 we cannot claim that the number of private sector opportunities which allow combination with the receipt of social assistance benefit differ between "insiders" and "outsiders". The estimated distributions of offered hours of work show a clear peak for full-time jobs in the public sector whereas there are fewer jobs with overtime hours than with part-time 
hours. By contrast, the private sector offers fewer part-time jobs than jobs with overtime. Finally, as is demonstrated by Table 3.2 all coefficients of the wage densities are precisely estimated with signs as expected. Wages are strictly concave functions of experience and increasing with education.

Table 3.1. Estimates of the parameters of the utility function

\begin{tabular}{|c|c|c|c|}
\hline Variable & Parameter & Estimate & Std. Dev. \\
\hline \multicolumn{4}{|l|}{ Consumption } \\
\hline & $\alpha_{1}$ & 0.9149 & 0.0513 \\
\hline & $\alpha_{2}$ & 4.3068 & 0.1385 \\
\hline \multicolumn{4}{|l|}{ Leisure } \\
\hline & $\alpha_{3}$ & -25.0167 & 0.8359 \\
\hline Constant & $\alpha_{4}$ & 1.8178 & 0.4205 \\
\hline Log age & $\alpha_{5}$ & -0.9662 & 0.2249 \\
\hline Log age squared & $\alpha_{6}$ & 0.1302 & 0.0303 \\
\hline \# children, 0 - 5 years old & $\alpha_{7}$ & 0.0095 & 0.0044 \\
\hline \# children, 6 - 12 years old & $\alpha_{8}$ & 0.0070 & 0.0021 \\
\hline \# children, 13 - 17 years old & $\alpha_{9}$ & 0.0022 & 0.0014 \\
\hline Employed in public sector & $\alpha_{10}$ & -0.0056 & 0.0027 \\
\hline Disabled, unemployed or long-term sick & $\alpha_{11}$ & 1.4166 & 0.3241 \\
\hline Receipt of social assistance & $\alpha_{12}$ & 4.8549 & 0.9869 \\
\hline \multicolumn{4}{|l|}{ Disutility } \\
\hline $\mathrm{z} \times \mathrm{Q}_{2}=1$ if children, 1 - 2 years old & $\tau_{1}$ & 1.4498 & 0.7139 \\
\hline $\mathrm{z} \times \mathrm{Q}_{3}=1$ if children, 3 years old & $\tau_{2}$ & 0.9869 & 0.4190 \\
\hline $\mathrm{z} \times \mathrm{Q}_{4}=1$ if children, 4 - 6 years old & $\tau_{3}$ & 0.1357 & 0.1963 \\
\hline $\mathrm{z} \times \mathrm{Q}_{5}=1$ if children, 7 - 10 years old & $\tau_{4}$ & -0.3638 & 0.2028 \\
\hline $\mathrm{z} \times \mathrm{Q}_{6}=1$ if children, 11 - 14 years old & $\tau_{5}$ & -1.8710 & 0.2123 \\
\hline $\mathrm{z} \times \mathrm{Q}_{7}=\mathbf{1}$ if Nationality=Swedish $(=1)$ & $\tau_{6}$ & -3.6231 & 0.1946 \\
\hline $\mathrm{z} \times \mathrm{Q}_{8}=1$ if lowest education $(\mathrm{de}=1)$ & $\tau_{7}$ & 0.8676 & 0.2036 \\
\hline
\end{tabular}


Table 3.2. Estimates of the choice set parameters

\begin{tabular}{|c|c|c|c|}
\hline & Parameter & Estimate & Std. Dev. \\
\hline The ratio between non-market opport. with and without social assist. & $\boldsymbol{\theta}$ & -4.0965 & 0.1941 \\
\hline \multicolumn{4}{|l|}{ Job/social assistance opportunity } \\
\hline public*social assistance & $\mu_{11}$ & -5.5278 & 0.2597 \\
\hline public*not social assistance & $\mu_{21}$ & -5.8326 & 0.2297 \\
\hline private* $^{*}$ social assistance & $\mu_{31}$ & -5.0786 & 0.3218 \\
\hline 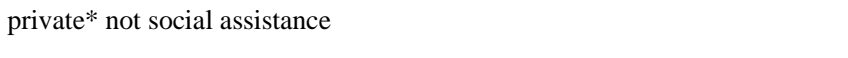 & $\mu_{41}$ & -4.9222 & 0.1919 \\
\hline public* social assistance *outsider & $\mu_{12}$ & -3.1195 & 0.9051 \\
\hline public* not social assistance *outsider & $\mu_{22}$ & -2.8042 & 0.2544 \\
\hline private* social assistance ${ }^{*}$ outsider & $\mu_{32}$ & -0.7433 & 0.7058 \\
\hline private* not social assistance *outside & $\mu_{42}$ & -1.1455 & 0.2402 \\
\hline \multicolumn{4}{|l|}{ Hours - Public sector } \\
\hline Part time & $\gamma_{01}$ & 0.4767 & 0.1399 \\
\hline Full time & $\gamma_{02}$ & 1.2272 & 0.1096 \\
\hline \multicolumn{4}{|l|}{ Hours - Private sector } \\
\hline Part time & $\gamma_{11}$ & -0.7091 & 0.0943 \\
\hline Full time & $\gamma_{12}$ & 0.2187 & 0.0461 \\
\hline \multicolumn{4}{|l|}{ Wage - Public sector } \\
\hline Constant & $\beta_{00}$ & 4.4284 & 0.0164 \\
\hline Experience/100 & $\beta_{01}$ & 0.7711 & 0.1087 \\
\hline Experience squared & $\beta_{02}$ & -1.2924 & 0.2787 \\
\hline High school & $\beta_{03}$ & 0.1227 & 0.0115 \\
\hline University education & $\beta_{04}$ & 0.3463 & 0.0131 \\
\hline Standard deviation & $\sigma_{0}$ & 0.1533 & 0.0018 \\
\hline \multicolumn{4}{|l|}{ Wage - Private sector } \\
\hline Constant & $\beta_{10}$ & 4.4583 & 0.0279 \\
\hline Experience/100 & $\beta_{11}$ & 1.1639 & 0.2418 \\
\hline Experience squared & $\beta_{12}$ & -2.7727 & 0.6051 \\
\hline High school & $\beta_{13}$ & 0.0366 & 0.0137 \\
\hline University & $\beta_{14}$ & 0.1948 & 0.0043 \\
\hline Standard deviation & $\sigma_{1}$ & 0.2114 & 0.0043 \\
\hline
\end{tabular}




\subsubsection{Wage and income elasticities}

To provide further information of the empirical model this sub-section presents labour supply elasticities. The wage elasticities are computed by means of stochastic simulations of the model since we (as analysts) do not observe all variables affecting preferences and opportunity sets. Job alternatives are drawn from the distributions of opportunities, whereas the associated random preference terms are drawn from the type I extreme value distribution. Given the responses of each individual we then aggregate over the individuals to get various types of aggregate elasticities. Table 3.3 displays the assessed wage elasticities. As opposed to the traditional labour supply models the random utility labour supply model will not react to small exogenous changes. For this reason the elasticities in Table 3.3 have been computed as an average of the per centage changes in labour supply from a 10 per cent increase in the wage rates.

Table 3.3. Labour supply elasticities with respect to wage for single mothers by deciles of disposable income.

\begin{tabular}{|c|c|c|c|}
\hline $\begin{array}{c}\text { Income decile } \\
\text { under the pre- } \\
\text { reform system }\end{array}$ & $\begin{array}{c}\text { Elasticity of } \\
\text { unconditional } \\
\text { expectation of } \\
\text { hours of work }\end{array}$ & $\begin{array}{c}\text { Elasticity of the } \\
\text { probability of } \\
\text { participation }\end{array}$ & $\begin{array}{c}\text { Elasticity of } \\
\text { conditional } \\
\text { expectation of } \\
\text { hours of work }\end{array}$ \\
\hline 1 & 4.44 & 1.82 & 1.77 \\
\hline 2 & 2.04 & 0.93 & 0.39 \\
\hline $3-8$ & 0.25 & 0.16 & 0.08 \\
\hline 10 & -0.02 & 0.00 & -0.04 \\
\hline All & 0.10 & 0.13 & -0.02 \\
\hline
\end{tabular}

Note: the elasticities in Table 3.3 and 3.4 has been computed as an average of the percentage changes in labour supply from a 10 per cent increase in the wage rates or non-labour income.

The second column of Table 3.3 gives the unconditional elasticities of labour supply, which means that the effects on participation as well as hours supplied are accounted for. The third column displays the elasticity of the probability of participation and the last column displays the elasticity of hours of work conditional on working. Last row summarizes the average results for all individuals. The overall unconditional elasticity is 0.45 , the most important effect is on the probability of working, 0.3 , whilst the effect on hours given work is 0.2. Moreover, as found in similar studies on Italian data (Aaberge et al., 1999, 2000), Norwegian data (Aaberge et al., 1995, 2000, 2013) and a previous data set for Sweden (Aaberge et al., 2000), the elasticities show to decline steeply with income. For the poorest decile the unconditional wage elasticity is equal to 4.44 and thus quite high.

The estimated income elasticities are reported in Tables 3.4. Non-labour income comprises several income categories, which are unevenly distributed among households and do not change 
uniformly in our simulation experiments. Since the income elasticities are household specific, the aggregate labour supply response to a shift that involves changes in non-labour income is the result of a complex calculation. Table 3.4 shows how the elasticity of labour supply with respect to changes in these incomes depend on the location in the income distribution. Except for high income households, the income effect is rather small which is consistent with results obtained for Italian and Norwegian data.

Table. 3.4. Labour supply elasticities with respect to non-labour income for single mothers by deciles of disposable income.

\begin{tabular}{|c|c|c|c|}
\hline Income decile under the pre-reform system & $\begin{array}{c}\text { Elasticity of } \\
\text { unconditional } \\
\text { expectation of } \\
\text { hours of work }\end{array}$ & $\begin{array}{c}\text { Elasticity of the } \\
\text { probability of } \\
\text { participation }\end{array}$ & $\begin{array}{c}\text { Elasticity of } \\
\text { conditional } \\
\text { expectation of } \\
\text { hours of work }\end{array}$ \\
\hline 1 & 0.12 & 0.06 & 0.00 \\
\hline 2 & 0.12 & 0.08 & 0.03 \\
\hline $3-8$ & -0.01 & -0.01 & -0.02 \\
\hline 9 & -0.02 & -0.03 & -0.03 \\
\hline 10 & -0.11 & -0.13 & -0.12 \\
\hline All & -0.01 & -0.01 & -0.03 \\
\hline
\end{tabular}

\subsubsection{In-sample prediction performance}

A comparison of the observed and simulated distributions of hours of work is given in Figure 3.1, which demonstrates that the simulated hours distribution reproduces the observed distribution quite well. The peak at zero hours as well as full time is almost exactly reproduced. Figure 3.2 provides the results of a similar exercise only for the "outsiders" and again we find that the model reproduces the observed distribution of hours of work quite well. 
Figure 3.1. Distribution of observed and predicted hours, all individuals

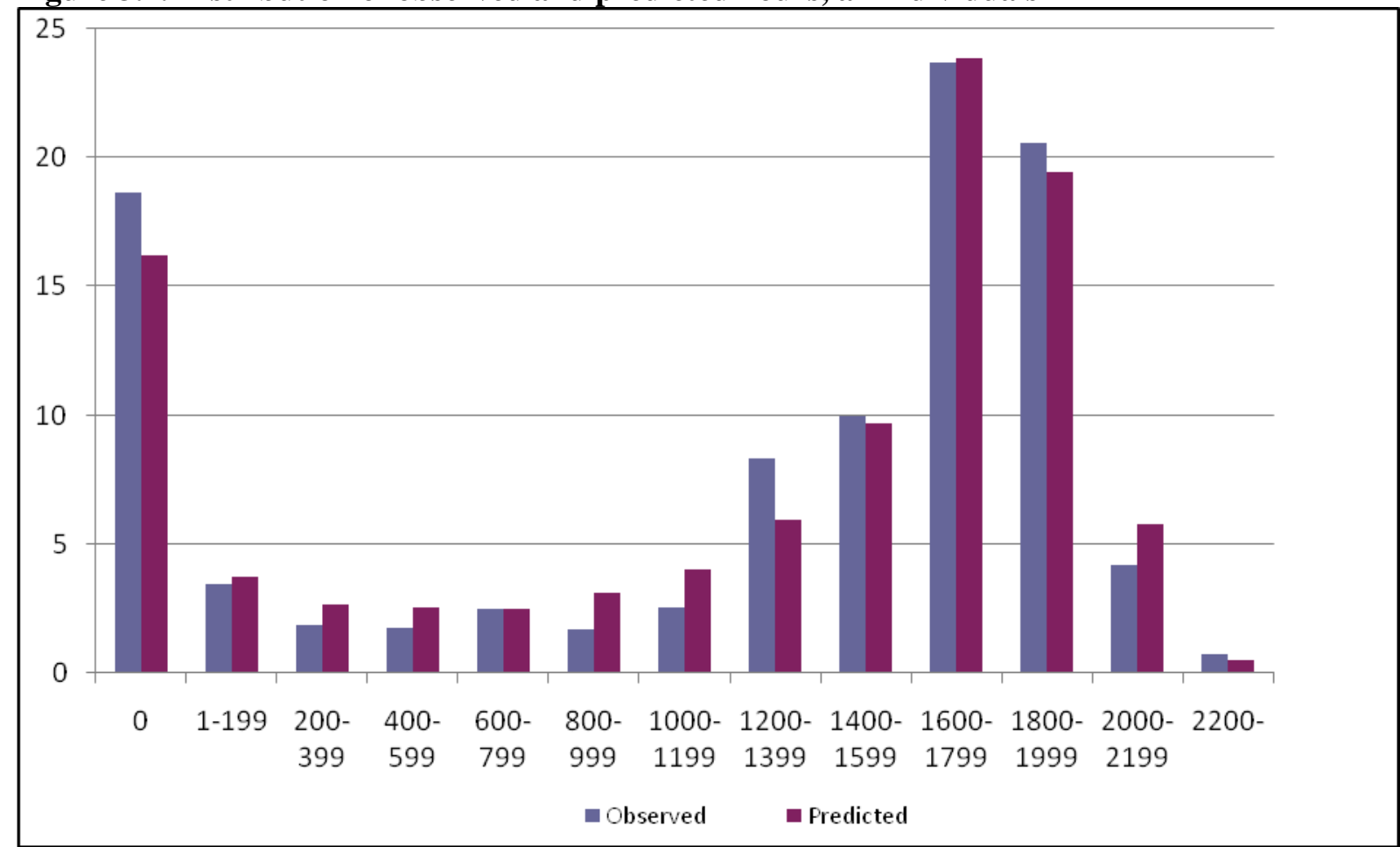

Figure 3.2. Distribution of observed and predicted hours, outsiders

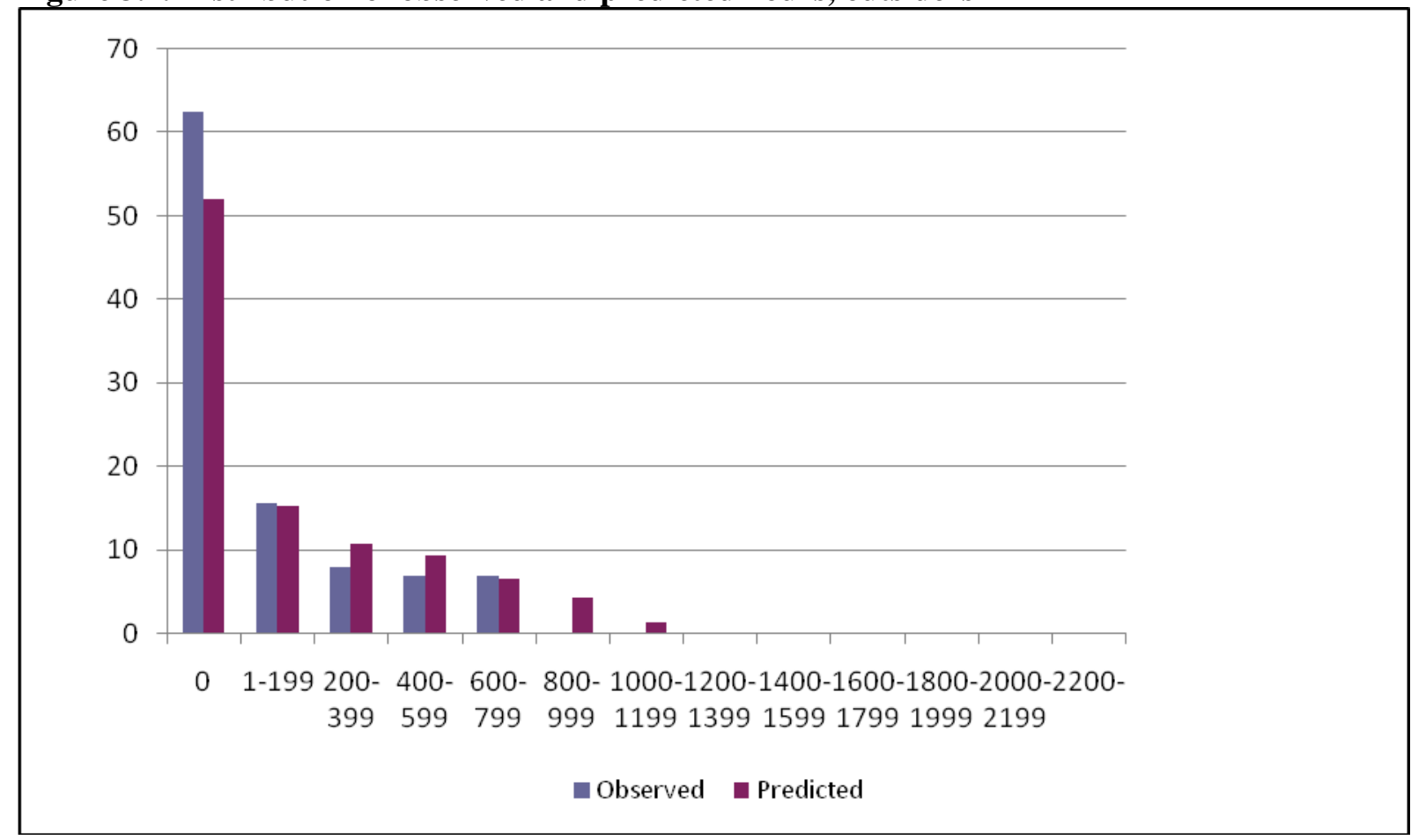




\subsubsection{Out-of-sample prediction performance}

The parameters have been estimated using data from 2004 and the model is shown to reproduce the observed distribution of hours of work (including non-participation) even for the outsiders quite well. However, the crucial question is how well the model performs in terms of out-of sample prediction. In order to demonstrate this performance we show a comparison of observed and predicted hours of work for 1992. Year 1992 is chosen because the macroeconomic conditions where roughly equal to the situation in 2004. As follows from Figures 3.3 the model reproduces the observed distributions in 1992 quite well.

Figure 3.3. Distribution of observed and predicted hours in 1992, all individuals

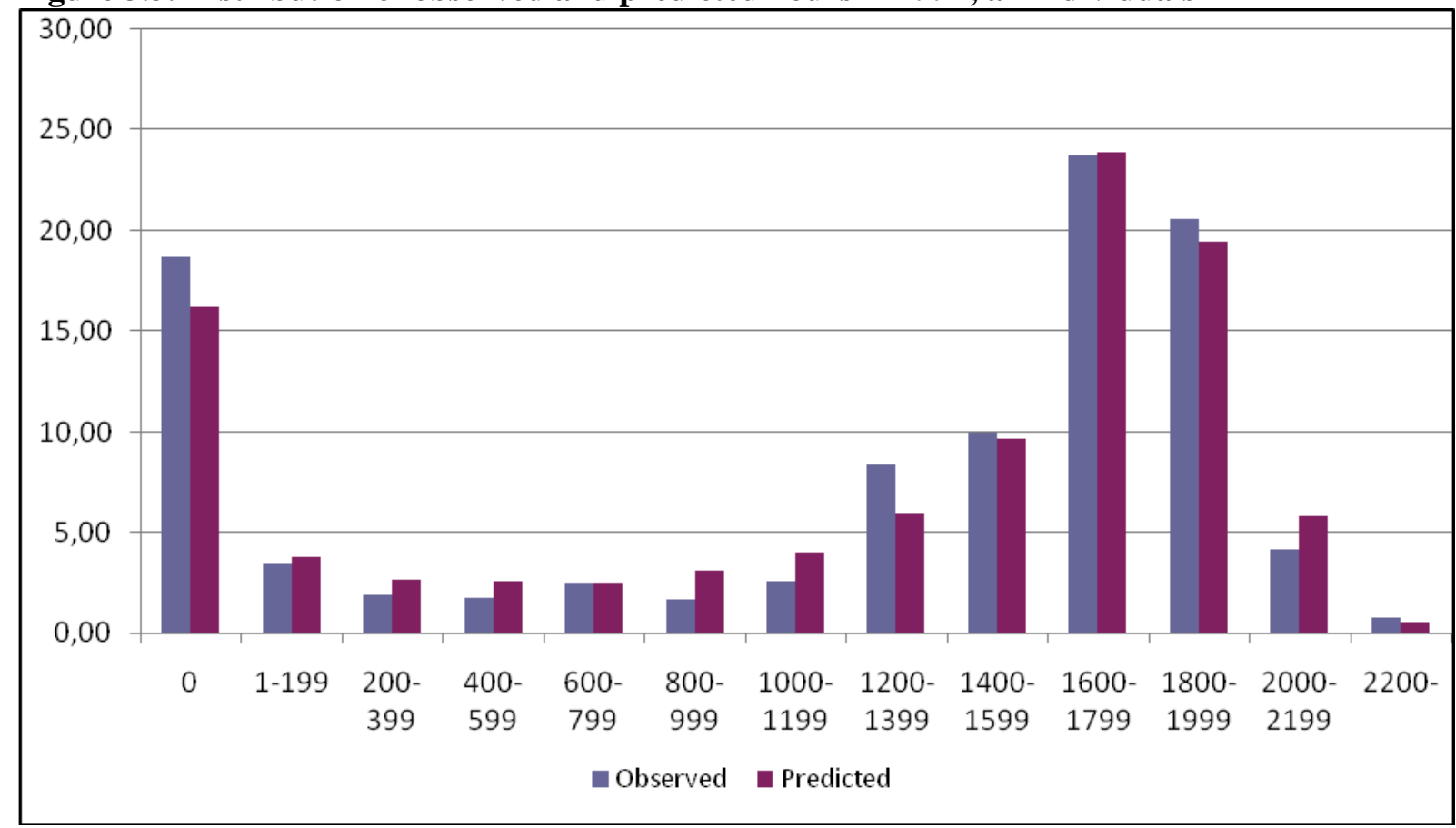

\section{Empirical results}

\subsection{Labour supply and income distribution effects}

Table 4.1 and 4.2 summarizes the welfare and distributional effects. By construction the evaluated reforms should not reduce welfare, for working individuals the reform implies reduced taxes and for non-working the tax is unchanged. For this reason Table 4.1 only presents the proportion of winners, however this proportion is quite different between the two reforms. Overall for the whole sample the JSA gives 83 per cent winners compared to 68 per cent for EITC. Thus to be precise about 
this difference, 83 per cent of all individuals have a higher utility after the JSA reform compared to before and 17 per cent have no change in utility. Accordingly 68 per cent have a higher utility under the EITC reform. Note, however, that there are more winners under EITC than under JSA among the 10 per cent poorest. Since the JSA is not phased out the proportion of winners are much higher for high income households under JSA compared to under EITC. Note the large difference for the top decile 93 per cent winners for JSA compared to only 26 per cent for EITC.

The effects on income inequality and poverty rates are displayed in Table 4.2. The direct effects for the JSA show a small increase in the Gini coefficient (from 0.184 to 0.193 ) the corresponding result for EITC is a reduction in Gini to 0.175. Again this is explained by the more generous tax reduction for low income households under the EITC. When the behavioural effects are accounted for we find a strong decrease in income inequality under EITC, which is due to a substantial increase in labour supply among the two poorest deciles and a reduction in hours of work among the remaining deciles. A similar pattern is found under the JSA system, which explains why the direct increasing inequality effect is counteracted by the behavioural effect. Before the reform the poverty rate is slightly below 9 per cent and both reforms reduce this rate but the reduction due to the EITC reform is significantly stronger.

Table 4.1. Proportions of winners by income deciles under the pre-reform tax system. Per cent

\begin{tabular}{|c|c|c|}
\hline Income decile under the pre-reform system & JSA & EITC \\
\hline 1 & & 48.3 \\
\hline 2 & 45.0 & 66.9 \\
\hline 3 & 64.7 & 79.2 \\
\hline 4 & 78.3 & 85.8 \\
\hline 5 & 85.3 & 91.7 \\
\hline 6 & 91.4 & 93.3 \\
\hline 7 & 93.1 & 88.6 \\
\hline 8 & 93.3 & 58.9 \\
\hline 9 & 93.1 & 37.8 \\
\hline 10 & 93.1 & 25.6 \\
\hline All & 92.8 & $\mathbf{6 7 . 6}$ \\
\hline
\end{tabular}

Table 4.2. Poverty rate and income inequality

\section{Before}

The Gini coefficient

At risk of poverty \%
JSA

$\begin{array}{cc}\text { Direct } & \text { Total } \\ .193 & .188 \\ 8.86 & 6.89\end{array}$

\section{EITC}

$\begin{array}{cc}\text { Direct } & \text { Total } \\ .175 & .164 \\ 5.33 & 3.58\end{array}$

Note: Disposable income is weighted according to an equivalence scale where one child less than 14 has the weight 0.3 and the weight for a child age 14 and above is 0.5 . Poverty is defined as an income below $60 \%$ of the median income. As median income SEK 145000 is used. 
Table 4.3 summarizes the effects of the two reforms on household disposable income. The direct non-behavioural effects of the tax changes show that the mean disposable income of single mothers increased by 5.6 per cent for JSA and 2.9 per cent for EITC. By accounting for behavioural effects we found that the mean disposable income increased further and contributed to a total increase of 9.1 per cent for JSA, whereas the behavioural effects from EITC were smaller and the total increase in income is only 1.1 per cent. Across the income distribution the results are significantly different between the non-behavioural and behavioural evaluation as well as between EITC and JSA. According to the non-behavioural evaluation the average increase in disposable income for individuals belonging to the first decile of the before reform disposable income distribution is on average 3.1 per cent for EITC and less than 1 per cent for JSA. The fact that the EITC are more generous than JSA for lowwage people explains the larger increase in disposable income for low income earners under the EITC reform than under JSA. However, by allowing for behavioural responses the average income of the first decile increases by 17.1 per cent for EITC and 21 per cent for JSA. As follows from the direct effect in Table 4.3, EITC is more generous up to the 4th decile and thereafter JSA becomes more generous.

Table 4.3. Direct and total effect of the JSA and EITC reforms on disposable income.

\begin{tabular}{|c|r|r|r|r|r|r|}
\hline Deciles & \multicolumn{2}{|c|}{$\begin{array}{c}\text { Pre-reform disposable } \\
\text { Income }\end{array}$} & \multicolumn{2}{c|}{ JSA } & \multicolumn{2}{c|}{ EITC } \\
\hline & SEK & \multicolumn{1}{|c|}{ USD } & $\begin{array}{c}\text { Direct } \\
\text { Effect. } \\
\text { Per cent }\end{array}$ & $\begin{array}{c}\text { Total } \\
\text { Effect. } \\
\text { Per cent }\end{array}$ & $\begin{array}{c}\text { Direct } \\
\text { Effect. } \\
\text { Per cent }\end{array}$ & $\begin{array}{c}\text { Total } \\
\text { Effect. } \\
\text { Per cent }\end{array}$ \\
\hline $\mathbf{1}$ & 112055 & 12590 & 0.86 & 20.96 & 3.06 & 17.06 \\
\hline $\mathbf{2}$ & 147884 & 16616 & 2.96 & 12.06 & 7.04 & 10.88 \\
\hline $\mathbf{3}$ & 170069 & 19109 & 4.75 & 10.59 & 7.35 & 8.26 \\
\hline $\mathbf{4}$ & 185577 & 20851 & 5.41 & 9.70 & 6.33 & 6.41 \\
\hline $\mathbf{5}$ & 199449 & 22410 & 6.60 & 10.01 & 5.69 & 4.84 \\
\hline $\mathbf{6}$ & 214863 & 24142 & 6.96 & 8.96 & 3.78 & 1.91 \\
\hline $\mathbf{7}$ & 232496 & 26123 & 6.95 & 8.18 & 2.17 & -1.89 \\
\hline $\mathbf{8}$ & 251217 & 28227 & 6.87 & 7.49 & 0.47 & -4.85 \\
\hline $\mathbf{9}$ & 278773 & 31323 & 6.32 & 6.96 & 0 & -5.56 \\
\hline $\mathbf{1 0}$ & 332658 & 37377 & 5.14 & 5.71 & 0 & -5.87 \\
\hline All & $\mathbf{2 1 2 5 0 4}$ & $\mathbf{2 3 8 7 7}$ & $\mathbf{5 . 6 3}$ & $\mathbf{9 . 0 7}$ & $\mathbf{2 . 8 9}$ & $\mathbf{1 . 1 0}$ \\
\hline
\end{tabular}

Allowing for changes in hours of work and hourly wage rates the overall picture of the reform effects change significantly, since JSA then produces a higher disposable income than EITC for all income deciles. As expected the percentage increase in disposable income is particularly high at lower income levels and declines by increasing income. The JSA implied an increase of about 6-7 per cent for the three top deciles, whereas the EITC implied a reduction of 5-6 per cent. However, as is clearly demonstrated by the results of Table 4.2, the changes in relative incomes, i.e. the changes in the corresponding Lorenz curves, show that the EITC Lorenz curve dominates the JSA Lorenz curve, 
which means that EITC produces a more equal income distribution than JSA. According, we can conclude that the US version of the in-work tax credit design creates a more equal income distribution at the cost of lower disposable income.

Table 4.4. Labour supply effects of the JSA and EITC reforms.

\begin{tabular}{|c|c|c|c|c|c|c|c|c|c|}
\hline \multirow[t]{3}{*}{ Deciles } & \multicolumn{3}{|c|}{ Participation } & \multicolumn{3}{|c|}{ Conditional on working } & \multicolumn{3}{|c|}{ Total effect } \\
\hline & \multirow[t]{2}{*}{$\begin{array}{l}\text { Before } \\
\text { the } \\
\text { reform }\end{array}$} & \multicolumn{2}{|c|}{$\begin{array}{c}\text { Change } \\
\text { due to } \\
\text { the reform } \\
\% \\
\end{array}$} & \multirow[t]{2}{*}{$\begin{array}{c}\text { Hours } \\
\text { before } \\
\text { the } \\
\text { reform } \\
\end{array}$} & \multicolumn{2}{|c|}{$\begin{array}{c}\text { Change } \\
\text { due to } \\
\text { the reform. } \\
\text { Per cent }\end{array}$} & \multirow[t]{2}{*}{$\begin{array}{c}\text { Hours } \\
\text { before } \\
\text { the } \\
\text { reform } \\
\end{array}$} & \multicolumn{2}{|c|}{$\begin{array}{c}\text { Change } \\
\text { due to } \\
\text { the reform. } \\
\text { Per cent } \\
\end{array}$} \\
\hline & & JSA & EITC & & JSA & EITC & & JSA & EITC \\
\hline 1 & 0.38 & 28.68 & 35.29 & 925 & 27.98 & 13.59 & 350 & 64.68 & 53.68 \\
\hline 2 & 0.61 & 8.72 & 11.47 & 1349 & 6.26 & -0.55 & 817 & 15.52 & 10.86 \\
\hline 3 & 0.77 & 3.99 & 3.99 & 1574 & 2.42 & -1.79 & 1206 & 6.50 & 2.12 \\
\hline 4 & 0.83 & 3.69 & 5.03 & 1650 & 1.23 & -3.52 & 1366 & 4.97 & 1.33 \\
\hline 5 & 0.93 & 1.50 & 0.90 & 1762 & 0.56 & -2.20 & 1630 & 2.07 & -1.32 \\
\hline 6 & 0.92 & 1.51 & 1.81 & 1870 & -0.06 & -3.95 & 1719 & 1.45 & -2.21 \\
\hline 7 & 0.93 & 1.19 & 1.49 & 1927 & 0.19 & -5.30 & 1793 & 1.39 & -3.89 \\
\hline 8 & 0.93 & 1.20 & 0.60 & 1938 & 0.10 & -5.44 & 1798 & 1.30 & -4.88 \\
\hline 9 & 0.93 & 1.19 & 0.30 & 2014 & -0.02 & -5.42 & 1874 & 1.17 & -5.13 \\
\hline 10 & 0.93 & 1.19 & 0.60 & 2041 & -0.39 & -4.52 & 1905 & 0.80 & -3.95 \\
\hline All & 0.81 & 3.62 & 4.02 & 1775 & 0.80 & -4.32 & 1446 & 4.45 & -0.47 \\
\hline
\end{tabular}

Table 4.4 shows that strong labour supply effects explain why the JSA reform produced much higher disposable income than EITC. The total labour supply effect, as measured by unconditional hours, increases by 4.5 per cent under the JSA reform whereas EITC reduces labour supply by 0.5 per cent. A further inspection of Table 4.4 shows that the important difference comes from the intensive margin. Whilst job participation rose by more than 3 per cent under both reforms, the introduction of JSA implied an increase of almost one cent in conditional hours of work whereas the EITC produced a decrease 4.4 per cent. Moreover, the effect on participation was rather similar across the income distribution for both reforms. The effect on participation was significant for the four lowest deciles, but rather modest for income levels above that. This result is in accordance with expectations, since the work requirement makes work pay for low-skilled people with low participation rates and hours of work.

As already mentioned the effect on the intensive margin, hours conditional on working, are very different for the JSA and EITC. For individuals located at the first decile hours of work increased by 28 per cent under JSA and 13.6 under the EITC. For higher deciles the increase are smaller under JSA and it even becomes negative for the two highest deciles as well as for decile 6 . However, under EITC there is a decrease in working hours for all income deciles except the first. The reason for why hours (conditional on working) increase with increasing pre-reform income is related to the effects of marginal tax rates (see Figure 4.3), since the EITC system produces a high marginal tax rate already 
for relatively low incomes. The strong negative effect on conditional hours for the EITC versus the JSA results in large reduction in disposable income for people located at deciles 7-10 (see Table 4.3).

Note that the result of Table 4.3 show even stronger reductions in disposable income then what is implied by the decrease in hours of work. This result is due to the fact the random utility model does not only account for changes in hours of work, but also in wages rates and non-pecuniary aspects of jobs. Tables 4.5 present more detailed information on changes in hours. The frequencies in different hours' intervals before the reforms are compared to the same intervals after the reform.

Starting at those individuals that did not work before the reform (18.56 per cent) the first line in the upper right panel shows that 15.61 per cent still had zero hours after the JSA reform compared to 15.28 after the EITC reform. It is informative to study the differences in the allocation of hours for the two reforms. The EITC reform results in a larger number of individuals choosing a small increase in working hours and fewer that makes large changes in their labour supply. For instance, 0.72 per cent of the individuals moved from zero to the largest group due to the JSA reform and only 0.03 due to the EITC reform. This reflects an important result relating to the evaluation of in-work-tax credit reforms. It is not only a high exit rate from non-participation that matters; the hours of work of the chosen job are crucial for total labour supply and income distribution effects as well as for the tax revenue. Since in-work tax credit systems like the EITC are designed to increase incentives at low hours the results obtained in this study is consistent with a priori expectations. Much the same can be repeated for the choice of hourly wage rates. The JSA reform results in more individuals that choose jobs with large wage increases compared to the EITC.

Table 4.5. Mobility in working hours due to the JSA and EITC reforms. First line in each cell refer to the JSA and the second line to the EITC. Per cent

\begin{tabular}{|c|c|c|c|c|c|c|c|}
\hline Before $\backslash A f t e r$ & 0 & $0-500$ & $500-1000$ & $1000-1500$ & $1500-2000$ & $>2000$ & Total \\
\hline \multirow[b]{2}{*}{$\mathbf{0}$} & 15.61 & 0.11 & 0.69 & 0.75 & 0.67 & 0.72 & \multirow[b]{2}{*}{18.56} \\
\hline & 15.28 & 0.61 & 1.00 & 0.97 & 0.47 & 0.03 & \\
\hline \multirow[b]{2}{*}{ 0- 500} & 0 & 2.33 & 0.19 & 0.14 & 0.14 & 0.14 & \multirow[b]{2}{*}{2.94} \\
\hline & 0 & 2.56 & 0.08 & 0.14 & 0.14 & 0.03 & \\
\hline \multirow[b]{2}{*}{$500-1000$} & 0 & 0 & 4.44 & 0.06 & 0.25 & 0.22 & \multirow[b]{2}{*}{4.97} \\
\hline & 0 & 0.22 & 4.28 & 0.28 & 0.17 & 0.03 & \\
\hline \multirow[b]{2}{*}{$1000-1500$} & 0 & 0 & 0 & 6.81 & 0.47 & 0.50 & \multirow[b]{2}{*}{7.78} \\
\hline & 0 & 0.03 & 0.03 & 7.56 & 0.14 & 0.03 & \\
\hline \multirow[b]{2}{*}{$1500-2000$} & 0 & 0 & 0.03 & 0.25 & 34.11 & 1.25 & \multirow[b]{2}{*}{35.64} \\
\hline & 0 & 0 & 0.25 & 1.69 & 32.94 & 0.75 & \\
\hline \multirow[b]{2}{*}{$>2000$} & 0 & 0 & 0.03 & 0.08 & 0.50 & 29.50 & \multirow[b]{2}{*}{30.11} \\
\hline & 0 & 0 & 0.25 & 1.89 & 3.72 & 24.25 & \\
\hline \multirow[b]{2}{*}{ Total } & 15.61 & 2.44 & 5.39 & 8.08 & 36.14 & 32.33 & \multirow[t]{2}{*}{100} \\
\hline & 15.28 & 3.42 & 5.89 & 12.53 & 37.58 & 25.31 & \\
\hline
\end{tabular}


The change in working hours and wage rates also affects eligibility and receipt of social assistance. Table 4.6 shows that the expenditure on social assistance drops by about 5 per cent according to the direct effects and more than 20 per cent when the behavioural effects are accounted for. Note that the total average effect is surprisingly equal for JSA and EITC. The same also holds for the lower income deciles, while they differ for individuals located at the higher deciles. The drop in social assistance due to JSA is stronger for decile 3 and 5 and for income above deciles 8 . Note that even high income household experiences a decrease in welfare participation. This is partly due to the fact that social assistance reflects family size and that a mother with many children can be eligible for assistance even though earnings are relatively high. Thus, in these cases social assistance contributes to the high disposable income.

Table 4.6. Effect on social assistance of the JSA and EITC reforms

\begin{tabular}{|c|c|c|c|c|c|c|}
\hline \multirow[t]{2}{*}{ Deciles } & \multirow{2}{*}{$\begin{array}{c}\begin{array}{c}\text { Social } \\
\text { assistance }\end{array} \\
\text { SEK }\end{array}$} & \multirow{2}{*}{$\begin{array}{c}\begin{array}{c}\text { Social } \\
\text { assistance }\end{array} \\
\text { USD }\end{array}$} & \multicolumn{2}{|c|}{$\begin{array}{c}\text { Percentage change } \\
\text { JSA }\end{array}$} & \multicolumn{2}{|c|}{$\begin{array}{c}\text { Percentage change } \\
\text { EITC }\end{array}$} \\
\hline & & & Direct effect & Total effect & Direct effect & Total effect \\
\hline 1 & 16202 & 1820 & -1.41 & -29.35 & -1.47 & -33.03 \\
\hline 2 & 14182 & 1594 & -3.15 & -31.91 & -3.72 & -39.43 \\
\hline 3 & 16246 & 1825 & -4.93 & -21.38 & -4.94 & -19.58 \\
\hline 4 & 14009 & 1574 & -4.92 & -26.08 & -4.92 & -30.64 \\
\hline 5 & 7763 & 872 & -5.23 & -19.28 & -5.23 & -13.61 \\
\hline 6 & 8829 & 992 & -5.28 & -14.96 & -5.28 & -17.54 \\
\hline 7 & 9258 & 1040 & -5.81 & -17.76 & -5.92 & -18.6 \\
\hline 8 & 9094 & 1022 & -5.55 & -24.19 & -5.55 & -15.54 \\
\hline 9 & 13105 & 1472 & -6.64 & -18.92 & -7.25 & -0.7 \\
\hline 10 & 15928 & 1790 & -7.46 & -10.5 & -8.06 & -6.18 \\
\hline All & 12462 & 1400 & -4.93 & -21.84 & -5.15 & -20.25 \\
\hline
\end{tabular}

To summarize, the steep phase-out of the EITC creates increased marginal tax rates even at relatively low income levels, which makes it less attractive to choose jobs with long hours and as a result disposable income might even decrease under the EITC reform. This effect gives a strong argument for using a JSA design without phase- out region. Thus, it's not only a question of searching for tax designs that create work incentives, since both JSA and EITC can be considered to be successful in this respect. The challenge is rather to create incentives for choosing jobs with longer hours. As demonstrated above the JSA and EITC differ with regard to incentive effects they create. The purpose of next subsection is to explore the revenue and expenditure effects of JSA and EITC. 


\subsection{Public budget effects}

This section focuses on the reform effects on government tax revenues and expenditures. Total taxes and benefits are assessed for each household before and after the reforms. Revenues are defined by the sum of income and payroll taxes, plus Value-Added Taxes (VAT) and also the childcare fees paid by the household. The cost of the reforms is assessed by changes in the amounts of housing allowances and social assistance received by the households. Table 4.7 summarizes the total effects of the reforms with and without behavioural effects. Before the reform the net revenue was found to be equal to 4,864 million USD. The direct (non-behavioural) effects of the reforms show that the net revenue decreases by more than 6 per cent under the JSA and only 3.5 per cent under the EITC, which is mainly due to a larger reduction in income taxes under JAS than under EITC explained by the fact that JSA is not phased out. The reduction in income taxes is partly compensated for by an increase in VAT and a reduction in the cost of social assistance. However, since the EITC has an even stronger reduction in social assistance the direct effect are clearly in favour of the EITC.

Table 4.7. Change in Governmental revenues and expenditures due to the JSA and the EITC reforms.

\begin{tabular}{|l|r|r|r|r|r|r|}
\hline & \multicolumn{2}{|c|}{$\begin{array}{c}\text { Before } \\
\text { the reform }\end{array}$} & \multicolumn{2}{c|}{ JSA reform } & \multicolumn{2}{c|}{ EITC reform } \\
& \multicolumn{1}{|c|}{$\begin{array}{c}\text { SEK } \\
\text { Million }\end{array}$} & $\begin{array}{c}\text { USD } \\
\text { Million }\end{array}$ & $\begin{array}{c}\text { Direct } \\
\text { Effect } \\
\text { \% }\end{array}$ & $\begin{array}{c}\text { Total } \\
\text { Effect } \\
\%\end{array}$ & $\begin{array}{c}\text { Direct } \\
\text { Effect } \\
\text { \% }\end{array}$ & $\begin{array}{c}\text { Total } \\
\text { Effect } \\
\%\end{array}$ \\
\hline (1) Income Taxes & 13310 & 2048 & -20.44 & -15.54 & -11.74 & -21.51 \\
\hline (2) Payroll Taxes & 13154 & 2024 & 0 & 5.97 & 0 & -4.92 \\
\hline (3) VAT & 8855 & 1362 & 6.03 & 8.54 & 3.22 & 0.49 \\
\hline (4) Child care fees & 710 & 109 & 0 & 5.92 & 0 & -3.8 \\
\hline (5) Housing allowance & 1231 & 189 & 0 & -13.89 & 0 & 2.84 \\
\hline (6) Social assistance & 3183 & 490 & -3.99 & -23.25 & -5.62 & -23.72 \\
\hline Total revenues 1+2+3+4 & 36030 & 5543 & -6.07 & -1.35 & -3.54 & -9.7 \\
\hline Total expenditures 5+6 & 4414 & 679 & -2.88 & -20.62 & -4.03 & -16.29 \\
\hline Revenues-Expenditures & $\mathbf{3 1 6 1 5}$ & $\mathbf{4 8 6 4}$ & $-\mathbf{6 . 5 1}$ & $\mathbf{1 . 3 4}$ & $\mathbf{- 3 . 4 7}$ & $\mathbf{- 8 . 7 7}$ \\
\hline
\end{tabular}

Notes: The payroll tax is $31,42 \%$ measured as a percentage of the wage rate net of payroll taxes. The VAT has been calculated as $20,6 \%$ on $100 \%$ of net-income.

The results presented above show that allowing for behavioural responses has a substantial effect on labour supply and the distribution of income. As a consequence the overall budget effect is positive for JSA and negative with a 9 per cent deficit for the EITC. The strong increase in labour income for the JSA reform produces a smaller decline in income taxes (-15.5 per cent) compared to the EITC reform (-21.5 per cent). Moreover, the increase in labour income contributes to increased 
payroll taxes as well as to higher disposable incomes and hence an increase in VAT. Moreover, expenses on housing allowance and social assistance decline.

To summarize, despite the large tax cuts the behavioural effects shows that the JSA reform even produced a small revenue surplus (1.3 per cent). As a contrast the EITC produces 9 per cent deficit.

\section{Conclusions}

The purpose of this paper is to compare a recent Swedish in-work tax credit reform with the American earned income tax credit. We pay particular attention to labour market exclusion; i.e. individuals in as well as outside the labour force are included in the analysis. To highlight the importance of the joint effects from the tax and the benefit systems it appears particular relevant to analyse the labour supply behaviour of single mothers. To this end, we estimate a structural microeconometric model of labour supply and welfare participation based on data for Swedish single mothers in 2004. The model accounts for heterogeneity in consumption-leisure preferences as well as for constraints in job opportunities.

To provide information of the basic features of the empirical labour supply model we compute the wage and income elasticities of each individual and present the results as exact aggregates for subgroups defined by income deciles. The overall wage elasticity derived from the estimated labour supply model is 0.45 per cent, where the contribution from the extensive margin proves to be larger than the contribution from the intensive margin. Moreover, the effects are significantly larger for single mothers with low incomes than for single mothers with higher incomes. The income effects are relatively small.

The results of the evaluation show that the Swedish reform generates substantial larger labour supply responses than the US version of the tax credit, which is consistent with the results of the analysis that Eissa and Hoynes (2011) conducted on the basis of US data for single mothers. The main explanation is that the US tax credit system has a steep phase-out region, whereas the Swedish tax credit is not phased out. Due to increased labour supply and decline in welfare participation we find that the Swedish reform is self-financing for single mothers, whereas a 9 per cent deficit follows from the EITC. However, where the Swedish tax credit system leads to increased income inequality the US version with phase-out reduces the income inequality.

How relevant are these results for the population of lone mothers in the US and for the current design of the EITC? Of course there are important institutional and labour market differences that raise issues of comparability. However there are also many similarities. The labour force participation 
is relatively high in Sweden but this is also the case in the US. ${ }^{15}$ An important difference is the relatively high level of the top marginal tax rate in Sweden and in fact this is one reason for not phasing out the JSA. The result would be an even higher top marginal tax rate during the income region where the credit is phased out. On the other hand very few lone mothers pay the highest tax rate, which means that the impact of the highest tax is rather limited.

It should be noticed that this study only considers the effect of the different profiles of the EITC and JSA. As discussed above there are also several other important differences. Still it is an interesting result that the more costly JSA without a phase-out region creates much stronger incentive effects and that the most important part comes from the intensive margin. This highlights an important effect: the design of the tax credit should not only aim at reducing the number of non-working individuals; it should also create incentives for full time work. Perhaps the most striking comparison is based on the difference in the hour wage mobility for the two reforms. Table 4.5 summarizes this change in hours before and after the reforms. Regardless of the before level in hours the JSA in general gives a higher proportion of individuals who moves to a higher hour level than the EITC. The EITC design creates incentives for working part time at median to low paid job. Note the difference in the change of hours for those not working before the reforms but also for those working long hours. Of those starting at long hours, over 2000 hours per year, almost 6 per cent change to a shorter working hours under EITC, the corresponding result under JSA is only 0.6 per cent. These changes in implied working and wage mobility have important income and governmental budget effect. An individual moving from zero or low hours of work to full time provides a double gain for the governmental budget. The cost of welfare is reduced and the tax revenues are increased. In fact these effects are so strong that the seemingly more expensive JSA even produce a budget surplus, whereas the modified EITC produces a deficit of approximately 9 per cent.

Since these results to a large extent are explained by the strong effects at the intensive margin a reasonable question is related to the robustness of these results. As been discussed earlier the estimated elasticities are in line with what has been reported in earlier studies. The results of Table 3.3 demonstrates that the conditional hours elasticities are very high for low incomes, rather small for medium incomes and negative for the highest incomes. This pattern confirms the importance of accounting for heterogeneity in preferences as well as in job opportunities. Thus, it is a great advantage of the microsimulation approach used in this paper that all intrinsic non-linear incentive effects are measured at the individual level. Moreover, exact aggregation over individual effects provides informative measures of total effects.

In order to evaluate the reliability of the simulation analyses the model, estimated on data

\footnotetext{
${ }^{15}$ According to OECD the employment rates for single parents age 15-64 is 81 and 75 per cent for Sweden and the US. Of course almost all single parents are single mothers. See http://www.oecd.org/els/soc/LMF1.3\%20Maternal\%20employment\%20by\%20family\%20status\%20\%20updated\%20090312.pdf
} 
from 2004, was used to predict labour supply of single mothers in 1992. Although the age and educational composition in 1992 differs from the composition in 2004 and the tax and benefit rules were changed the model provides reliable out-of-sample predictions.

\section{References}

Aaberge, R., J.K. Dagsvik and S. Strøm (1995): "Labour Supply Responses and Welfare Effects of Tax Reforms”, Scandinavian Journal of Economics, 97, 4, 635-659.

Aaberge, R., U. Colombino and S. Strøm (1999): "Labour Supply in Italy: An Empirical Analysis of Joint Household Decisions, with Taxes and Quantity Constraints”, Journal of Applied Econometrics, 14, 403-422.

Aaberge, R., U. Colombino and S. Strøm (2000): “Labor Supply Responses and Welfare Effects from Replacing Current Tax Rules by a Flat Tax: Empirical Evidence from Italy, Norway and Sweden”, Journal of Population Economics, 595-621, 2000.

Aaberge, R., U. Colombino and T. Wennemo (2009): "Evaluating Alternative Representations of the Choice Sets in Models of Labour Supply”, Journal of Economic Surveys, 3, 586 - 612, 2009.

Aaberge, R. and U. Colombino (2013): "Designing Optimal Taxes with a Microeconometric Model of Labour Supply”, Scandinavian Journal of Economics, 115, 449-475.

Ben-Akiva, M. and T. Watanatada (1981) Application of a Continuous Spatial Choice Logit Model, in Manski, C. F. and McFadden D. (eds.) Structural Analysis of Discrete Data with Econometric Applications, MIT Press.

Blank, R. M. (2002): “Evaluating welfare reform in the United States”, Journal of Economic Literature, 40, 1105 - 1166.

Blundell, R. (2006): "Earned Income Tax Credit Policies: Impact and Optimality.The Adam Smith Lecture 2005”, Labour Economics, 13, 423-443.

Blundell, R., A. Duncan, J. McCrae and C. Meghir (2000): “The labour market behavior of the Working Families Tax Credit”, Fiscal Studies, 21, 75 - 103.

Blundell, R., and H. Hoynes (2004): “Has ”in-work” benefit reform helped the labour market?” In: R. Blundell, D. Card and R.B. Freeman eds., Seeking a Premiere League Economy, 411 - 460, Chicago: University of Chicago Press.

Blundell, R., M. Brewer, P. Haan and A. Shephard (2009): Optimal Income Taxation of Lone Mothers: An Empirical Comparison of the UK and Germany, Economic Journal, 119, F101-F121.

Blundell, R. and A. Shephard (2011): "Employment, Hours of Work and the Optimal Taxation of Low Income Families”, Review of Economic Studies.

Boadway R., Marchand M., Pestieau P. and M. Racionero (2002): “Optimal Redistribution with Heterogeneous Preferences for Leisure”, Journal of Public Economic Theory, 4, 475 - 498. 
Brewer, M. (2001): “Comparing in-work benefits and the reward to work for low-income families with children in the US and UK", Fiscal Studies, 22, 41 - 77.

Brewer, M. (2009): “How do income-support systems in the UK affect labour force participation?”, IFAU Working Paper 2009:27.

Brewer, M, A, Duncan, A. Shepard and M-J. Suárez (2006): “Did Working Families Tax Credit work?” The impact of in-work support on parents labour supply and take-up behavior in Great Britain”, Labour Economics, 13, 699 - 720.

Brewer, B., M. Francesconi, P. Gregg and J. Grogger (2009): "Feature: In-work benefit reform in a cross-sectional perspective -Introduction”, The Economic Journal, 119, F1 - F14.

Dagsvik, J.K. (1994): Discrete and Continuous Choice, Max-Stable Processes and Independence from Irrelevant Attributes, Econometrica, 62, 1179-1205.

Dickens, W. and S. Lundberg (1993): Hours Restrictions and Labour Supply, International Econonomic Review, 34, 169-191.

Edin, P. A., and Fredriksson, A., ”LINDA - Longitudinal INdividual DAta for Sweden” www.nek.uu.se/ (2000).

Edmark, K., C-Y Liang, E Mörk and H Selin (2012): "Evaluation of the Swedish earned income tax credit”, IFAU working paper 2012:1

Eissa, N. and H. Hoynes (2004). "Taxes and the Labour Market Participation of Married Couples: The Earned Income Tax Credit," Journal of Public Economics, 88, 1931-1958.

Eissa, N. and H. Hoynes (2006): ”Behavioural Responses to Taxes: Lessons from the EITC and Labour Supply," In James Poterba, ed. Tax Policy and the Economy 20, Cambridge: MIT Press, pp. 74-110.

Eissa, N. and H. Hoynes (2011): "Redistribution and Tax Expenditures: the Earned Income Tax Credit”, National Tax Journal, 64, 689-730.

Eissa, N., H. Kleven and C. Kreiner (2008): "Evaluation of four tax reforms in the United States: labour supply and welfare effects for single mothers”, Journal of Public Economics, 92, 795 - 816.

Fang H. and M. Keane (2004) 'Assessing the Impact of Welfare Reform on Single Mothers', Brookings Papers on Economic Activity 1: 1-116.

Flood, L., J. Hansen and R. Wahlberg (2004): "Household Labour Supply and Welfare Participation in Sweden”, Journal of Human Resources, 39, 1008 - 1032.

Flood, L., R. Wahlberg and E. Pylkänen (2007), ’From Welfare to Work: Evaluating a Proposed Tax and Benefit Reform Targeted at Single Mothers in Sweden”, Labour, 21, 443-471.

Flood, L., L Behrenz, H Edquist and S Lundgren (2008): “Vägar till full sysselsättning”: Konjunkturrådets rapport 2008, SNS förlag.

Francesconi, M. and W. van der Klaauw (2007): "The Socioeconomic Consequences of "In-Work" Benefit Reform for British Lone Mothers," Journal of Human Resources, 42, 
French, E., and J. Song (2013): “The Effect of Disability Insurance Receipt on Labor Supply, Appeals and Re-Applications: Evidence from Hearing Office Level Decisions”, American Economic Journal: Applied (To appear).

Grogger, J. (2003): "The Effects of Time Limits, the EITC, and other Policy Changes on Welfare Use, Work, and Income among Female-Headed Families”, The Review of Economics and Statistics, 85, 394-408.

Grogger, J. and L. A. Karoly ((2005): Welfare Reform: Effects of a Decade of Change, Cambridge, MA: Harvard University Press.

Haan, P. and M. Myck (2007): “Apply with Caution: Introducing UK-style In-work Support in Germany”, Fiscal Studies, 28, 43 - 72.

Hotz, V. J. and J. K. Scholz (2003). \The Earned Income Tax Credit" in R. Mofitt_(ed.), Means-Tested Transfer Programs in the United States. Chicago: University Chicago Press.

Kostøl, A. and Mogstad, M. (2013). "How Financial Incentives Induce Disability Insurance Recipients to Return to Work", American Economic Review (to appear).

Labeaga, J.M., X. Oliver and A. Spadaro (2007): "Discrete choice models of labour supply, behavioural microsimulation and the Spanish tax reforms”, The Journal of Economic Inequality, DOI 10.1007/s10888-007-9057-9.

Maestas, N., K. Mullen and A. Strand (2012): “Does Disability Insurance Discourage Work?” American Economic Review (To appear).

McFadden, D. (1981) “Econometric Models of Probabilistic Choice”, in Manski, C and McFadden, D eds., Structural Analysis of Discrete Data with Econometric Applications, MIT Press: Cambridge, 1981, 198-272.

Meyer, B.D., D.T. Rosenbaum (2001): "Welfare, the earned income tax credit, and the labour supply of single mothers”, Quarterly Journal of Economics, 116, 1063-1114.

Meyer, B. D. and D. Holtz-Eakin (2002): Making Work Pay:The Earned Income Tax Credit and Its Impact on American Families. Russel Sage Foundation, New York, NY.

Moffitt, R. (1983):” An economic model of welfare stigma”, American Economic Review, 73, 10231035.

Moffitt, R. (2006): "Welfare work requirements with paternalistic government preferences”, The Economic Journal, 116, F441 - F458.

Socialstyrelsen (2012), Ekonomiskt bistånd årsstatistik 2011. 2012-6-58

Statistics Sweden (2004), Income Distribution Survey 2004. HE 21 SM 0601

van Soest, A. (1995): Structural Models of Family Labor Supply: A Discrete Choice Approach, Journal of Human Resources 1 , 63-88. 


\section{Appendix}

\section{Description of the data}

The data was taken from the Swedish register-based LINDA ${ }^{16}$. LINDA consists of a large panel of individuals and their household members; the sample used in this study comes from the 2004 wave of LINDA. We included single mothers older than 24 and younger than 56 with 1 to 5 children, the youngest being 17 year or younger. The lower age limit exclude the problem of modelling choice of education and the upper follows from the age limit of youngest children, only a few full time students older than 25 were excluded. Information on incomes, wages, transfers, taxes, educational attainments was obtained from various government registers.

The definition of a household is a problem in most administrative data, and LINDA is no exception. For economic analysis the most natural would be to define "household" as an economic unit, but since LINDA is based completely on register information it is not always possible to get correct information about the household composition. There is then a possibility that the number of single mothers may be overestimated if, for instance, she is living together with a man without being married and without having common children. We have not tried to adjust for this, but according to alternative data sources ${ }^{17}$, which are survey-based and therefore use an economic definition, the differences are quite small. About 5 per cent of all households in Sweden 2004 can be classified as headed by single mothers.

Wage data was collected from the official statistics by Statistics Sweden, based on employers' reports. Employers report monthly earnings, expressed in full-time equivalents and giving the amount the individual would have earned if working full-time. To obtain hourly wage rates, the monthly earnings are divided by 165 . Yearly hours of work, h, is then defined as total labour earnings divided by the hourly wage rate. The hourly wage rate used here is quite different from that obtained by dividing observed earnings by observed hours, which has a tendency to include measurement errors. The data used here is not subject to the same problem. However, there are missing values from the employers reported earnings and if there is a positive reported income from work but no monthly earnings reported from the employer, then we delete that individual. Thus, we are deleting some of the workers and to compensate for this we have also deleted some non-workers randomly in order to keep the participation rate intact. We ended up with a sample of 3,600 single mothers.

As usual, a remaining problem is that wage rates are missing for non-working individuals. Note that the labour supply model also includes estimation of a wage equation. Still a wage equation is estimated and based on the estimates predicted mean values and variances are used for data

\footnotetext{
${ }^{16}$ For a description of LINDA see Edin and Fredriksson (2000).
} 
generation.

The total income of a household consists of both earned and unearned income. Unearned incomes include any capital gains, the national child allowance, and any child-support payments. Unemployment benefits and other transfers that depend on labour supply were excluded from our measure of unearned income.

Unfortunately, there is no information in LINDA about housing rent or about how many households use municipal childcare. Therefore, the rent of housing was imputed using information from an alternative data source, the Swedish Household Income Survey 2004, also supplied by Statistics Sweden. In the imputation we used the method of minimum-distance, using age, number of children, earnings, place of residence, and citizenship as classification variables. The childcare fees could still be calculated since the rules are known and since the take-up ratio is high we assume that everyone utilize municipal child-care.

In LINDA there is register-information on the number of months each household received social assistance (as well as the amount received), but not which months. ${ }^{18}$ Thus we were not able use monthly data in the analysis, but instead aggregated all information to an annual basis. A household is then defined as a recipient if it received more than SEK 12,000 during the year. Most of the SAhouseholds received benefits for a short period. Of all the SA-recipients, about 60 per cent received it for six months or less.

To generate disposable income for various combinations of hours of work and welfare, we use a modified version of the micro-simulation model (FASIT). ${ }^{19}$ FASIT contains very precise information on income tax rules, as well as eligibility-rules for a number of welfare programs, such as social assistance and housing allowance. It also enabled us to calculate cost of childcare. Access to a simulation-model such as FASIT was essential for calculating accurate (net) household incomes, conditional on labour supply, because income tax rules and the various welfare benefit-levels are complicated functions of earned and unearned income.

The variables included in the utility function were: age, education, dummy variables for the age of the children; a dummy variable indicating if the single mother was born in Sweden; and finally, years of experience.

In this study the sample has been divided into employed, unemployed, long-term sickness, disability pension and also voluntary non-workers (individuals not supported on unemployment or sick/disability benefit). The classification into these groups is done according to the income source. An individual with the bulk part of her income from work is classified as employed, if most of the income comes from unemployment benefit the individual is classified as unemployed and so on. The income

\footnotetext{
${ }^{17}$ Statistics Sweden (2004), Income distribution Survey 2004.

${ }^{18}$ Having access to register-data on welfare participation is a great advantage compared to interview-data, as there is no under-reporting of welfare participation in register-data.
} 
limits has been selected in such way that the results is comparable to information from Statistical Sweden, based on the labour force study.

Table A.1 presents descriptive statistics for the sample used for the empirical analysis. The information is given for the total as well as for each sub-group. The bottom line shows that out of the total 3,600 households, 73 per cent are employed and 6 per cent classified as other that is individuals without support from disability/sickness/unemployment-benefit. The "outsiders” are of equal size, unemployed 7 per cent, disability and sickness 6 per cent. In general, the characteristics of the nonemployed individuals differ from the employed. For instance, only 2 per cent of individuals classified as disabled have the highest education compared to 18per cent for the employed. Age and years of experience indicate that unemployed are younger and disabled are older. The distribution of children is similar with the exception that the younger children are more frequent amongst unemployed and other. Among those employed almost 70 per cent are in the public sector.

For the distribution of income and working hours across the different groups, it is important to remember that the outsiders can work part of the year. It follows from the statistics that the overall participation rate is about 80 per cent and that a large share of unemployed and long-term sick have had some working spell during the year but much less so for disabled. However, information on working hours shows that they had worked few hours. Since working hours and distribution of hours is of a major interest in this study Figure 3.1 gives the frequencies for working hours for the full sample and Figure 3.2 for the "outsiders". The high ratio of non-participation and the presence of short working hours is a result of including the "outsiders".

Income from work of course reflects working hours and to some degree differences in wage rates. Non-labour income includes income of capital and some non-means tested transfers. Note that the mean of non-taxable non-labour income is negative, thus loans are frequent especially for those with a labour income. Even if there are large differences in labour income as expected the differences in disposable income is much smaller. Disability/sickness/unemployment-benefit as well as social assistance is the main explanation. On average 6 per cent of the sample has received more than SEK 12,000 during the year. It follows that there is a large across-group variation; from 66 per cent for "other" to one per cent for employed.

\footnotetext{
${ }^{19}$ FASIT was developed and is used by Statistics Sweden and the Swedish Ministry of Finance.
} 
Table A.1. Descriptive statistics a 2004 Linda sample of single mothers

\begin{tabular}{|c|c|c|c|c|c|c|}
\hline Variable & Total & Disability & Unemployed & Other & Sickness & Working \\
\hline Age & 40.72 & 43.39 & 37.67 & 39.14 & 39.69 & 41.01 \\
\hline Highest education first level & 0.16 & 0.37 & 0.20 & 0.50 & 0.24 & 0.11 \\
\hline Highest education secondary level & 0.69 & 0.61 & 0.74 & 0.46 & 0.68 & 0.71 \\
\hline Highest education tertiary level & 0.15 & 0.02 & 0.06 & 0.04 & 0.07 & 0.18 \\
\hline Years of working experience & 19.84 & 23.87 & 17.47 & 20.75 & 19.83 & 19.65 \\
\hline Born in Sweden yes $=1$ & 0.83 & 0.75 & 0.72 & 0.54 & 0.81 & 0.87 \\
\hline Number of children age $0-5$ & 0.13 & 0.09 & 0.27 & 0.30 & 0.15 & 0.10 \\
\hline Number of children age 6-12 & 0.60 & 0.43 & 0.78 & 0.83 & 0.69 & 0.57 \\
\hline Number of children age $13-17$ & 0.70 & 0.87 & 0.51 & 0.61 & 0.71 & 0.70 \\
\hline Employed in public sector, yes $=1^{*}$ & 0.69 & 0.00 & 0.86 & 0.00 & 0.51 & 0.69 \\
\hline Working, yes $=1$ & 0.81 & 0.04 & 0.58 & 0.00 & 0.46 & 1.00 \\
\hline Yearly working hours & 1398 & 7 & 297 & 0 & 231 & 1849 \\
\hline Hourly wage rate & 128 & 120 & 119 & 120 & 122 & 130 \\
\hline Yearly earnings (WH) & 194842 & 2059 & 46078 & 3364 & 159460 & 243424 \\
\hline Yearly Taxable non-labour income & 11416 & 19449 & 18497 & 31261 & 10514 & 8661 \\
\hline $\begin{array}{c}\text { Yearly non-taxable non-labour } \\
\text { income** }\end{array}$ & -2072 & 110 & 1094 & 1901 & -1427 & -2924 \\
\hline Deductions $^{* * *}$ & 3800 & 568 & 1152 & 293 & 1488 & 4835 \\
\hline Yearly Disposable income & 197471 & 173638 & 170291 & $\begin{array}{l}146 \\
737\end{array}$ & 179862 & 207772 \\
\hline Social assistance, yes $=1$ & 0.06 & 0.12 & 0.08 & 0.66 & 0.10 & 0.01 \\
\hline Outsider, yes $=1^{* * * *}$ & 0.21 & 1.00 & 1.00 & 0.00 & 1.00 & 0.00 \\
\hline Share & 1.00 & 0.06 & 0.07 & 0.06 & 0.08 & 0.73 \\
\hline
\end{tabular}

Source: LINDA 2004

Note, Total sample size 3600

*) Calculations based on 2703 individuals, who are 1=public and 0=privately employed and 297 individuals are not employed.

**) The negative mean value is explained by negative capital.

$* * *$ ) Deductions are mainly cost of commuting to work and part of premium for private pension savings.

$* * * *$ ) Unemployed, disability pension and long term sick, yes=1 